\title{
Bir Öğrenme Yönetim Sistemi Üzerinden Yürütülen Lisansüstü Derslerin Süreç Değerlendirmesi: AYDEP Örneği
}

\author{
Menderes ÜNAL \\ Kırşehir Ahi Evran Üniversitesi \\ menderesunal@gmail.com \\ ORCID: 0000-0001-9439-3308 \\ Murat ÇOKYAMAN \\ Milli Ĕgitim Bakanlı̆̆ \\ m.cokyaman@hotmail.com \\ ORCID: 0000-0002-9682-5036
}

\begin{tabular}{lrr} 
Araştırma Makalesi & DOI: 10.31592/aeusbed.907624 \\
\hline Geliş Tarihi: 01.04.2020 & Revize Tarihi: 09.06.2021 & Kabul Tarihi: 05.07.2021
\end{tabular}

\section{Atıf Bilgisi}

Ünal, M. ve Çokyaman, M. (2021). Bir öğrenme yönetim sistemi üzerinden yürütülen lisansüstü derslerin süreç değerlendirmesi: AYDEP örneği. Ahi Evran Üniversitesi Sosyal Bilimler Enstitüsü Dergisi, 7(2), 620-639.

\section{ÖZ}

Teknolojinin 21. yüzyılda hızlı bir şekilde gelişmesiyle birlikte ortaya çıkan sanal öğrenme ortamları uzaktan eğitim için önemli bir dönüm noktası olan Öğrenme Yönetim Sistemlerinin gelişmesine neden olmuştur. Bu sistemlerden bir tanesi de Ahi Yeterliğe Dayalı Eğitim Portalıdır (AYDEP). Bu çalışmada AYDEP Öğrenme Yönetimi Sisteminin değerlendirilmesi ve bu sistem üzerinden yürütülen lisansüstü ders etkinliklerinin Stufflebeam'in Bağlam, Girdi, Süreç ve Ürün Değerlendirme Modeli olarak da bilinen CIPP Program değerlendirme modeline göre değerlendirilmesi amaçlanmıştır. Çalışmada nicel araştırma yöntemlerinden betimsel araştırma (tarama) modeli kullanılmıştır. Çalışma evrenini Kırşehir Ahi Evran Üniversitesi Sosyal Bilimler Enstitüsünde lisansüstü öğrenim görmekte olan öğrenciler ve derslere giren öğretim elemanları oluşturmaktadır. Çalışmaya 171 öğrenci ve 40 öğretim elemanı katılmıştır. Çalışmada veri toplamak için AYDEP Değerlendirme Anketi ve CIPP Modeli Süreç Değerlendirme Anketi kullanılmıştır. Araştırmadan elde edilen veriler uygun bir istatistik programına aktarılarak çalıșma amaçları doğrultusunda yüzdelik oranları, frekans değerleri ve aritmetik ortalamaları tespit edilmiş ayrıca bağımsız gruplar t-testi ve Tek Yönlü Varyans Analizi (ANOVA) testi ile analiz edilmiştir. Araştırma sonucunda katılımcıların AYDEP Öğrenme Yönetim Sistemini faydalı buldukları ve CIPP Program Değerlendirme Modeli süreç boyutu ölçütlerine göre de lisansüstü ders etkinliklerinden memnun oldukları tespit edilmiştir.

Anahtar Kelimeler: AYDEP, CIPP modeli, öğrenme yönetim sistemi.

\section{Process Evaluation of Graduate Courses Conducting Through a Learning Management System: AYDEP Sample}

\begin{abstract}
Online learning environments emerged with the rapid development of the technology in the 21 st century have led to the development of Learning Management Systems, which is an important milestone for distance education. One of these systems is the Ahi Competence Based Education Portal (AYDEP). In this study, it was aimed to evaluate the AYDEP Learning Management System and to evaluate the graduate course activities conducted through this system according to Stufflebeam's CIPP Program Evaluation Model, also known as Context, Input, Process and Product Evaluation Model. Descriptive survey model, one of the quantitative research methods, was used in the study. The universe of the study consists of graduate students and lecturers at the Institute of Social Sciences at Kırşehir Ahi Evran University. 171 students and 40 lecturers participated in the study. AYDEP Evaluation Questionnaire and CIPP Model Process Evaluation Questionnaire were used to collect data in the study. Percentages, frequencies and arithmetic means were determined, independent groups t-test and One-Way Analysis of Variance (ANOVA) were applied. As a result of the research, it was determined AYDEP Learning Management System was useful according to participants and they were satisfied with the graduate course activities according to the process dimension of CIPP Program Evaluation Model.
\end{abstract}

Keywords: AYDEP, CIPP model, learning management system.

\section{Giriş}

Bilgi ve iletişim teknolojilerinde yaşanan hızlı gelişmeler, her alanda olduğu gibi eğitim ve öğretim alanında da birtakım değişimleri ortaya çıkarmaktadır. Bu değişimin altında teknolojik aletlere kolay erişim kadar bireylerin değişen ihtiyaçları ve eğitim öğretime yönelik paradigmal dönüşümler 
yatmaktadır. Dijital aletlerin günlük hayatın vazgeçilmez bir parçası olduğu ve giderek artan bir şekilde günlük hayatımızı etkilediği bu günlerde, bireylerin zaman ve mekân fark1 gözetmeksizin öğrenme ortamlarına katılabilecekleri sistemlerin kullanılmasına yönelik arayış sürmektedir. Çünkü bireyler daha esnek öğrenme yöntemleri ile öğrenme ihtiyaçlarını karşılamak istemektedirler. Bu bağlamda Kırık'ın (2014) belirttiği üzere geçmişi 1728'li y1llara dayanan ve Amerika'da mektupla stenografi dersleriyle başlayan "Uzaktan Eğitim" kavramı karşımıza çıkmaktadır. Uzaktan eğitimin tarihsel gelişimini Moore ve Kearsley (2002) "Mektuplaşma" (1. nesil), "Radyo ve televizyon" (2. nesil), "Açık üniversiteler" (3. nesil), "Telekonferans" (4. nesil) ve "İnternet/Web" (5. nesil) olmak beş aşamada incelemektedir. Özellikle son yıllarda bilgi ve iletişim teknolojilerindeki gelişmelere paralel olarak internetin yaygınlaşmasıyla uzaktan eğitim 5. nesil döneminde geniş bir kullanım alanı bulmuştur (Al ve Madran, 2004; Bozkurt, 2017; Elitaş, 2017; Rovai ve Barnum, 2003; Sezer 2019).

Teknolojinin hızla gelişmesiyle birlikte ortaya çıkan sanal öğrenme ortamları uzaktan eğitim için önemli bir firsat sunmaktadır. Al ve Madran (2004) uzaktan eğitimin arzu edilen kaliteye ulaşması ve yeterli öğrenen-öğreten-eğitim materyali etkileşiminin internetin bir eğitim platformu olarak kullanılmaya başlanmasıyla gerçekleştiğini ifade etmektedir. Moore ve Kearsley'in (2002) 5. nesil olarak adlandırdığı bu uzaktan eğitim formatı, internet tabanlı uzaktan eğitimin ortaya çıkmasına internete dayalı uzaktan eğitim de Öğrenme Yönetim Sistemlerinin (ÖYS) geliştirilmesine zemin hazırlamıştır. Kullanıcıların tanımlanması ve yönetilmesi, ders içeriklerinin yönetilmesi, ödev sistemi, sınav uygulama sistemi, öğrenci davranışlarının izlenmesi, öğrenci başarı durumlarının değerlendirilmesi ve iletişim araçlarının yönetilmesi gibi işlevleri barındıran internet tabanlı uzaktan eğitim ÖYS adı verilen özel yazılımlarla sağlanmaktadır (Al ve Madran, 2004).

İnternet tabanlı uzaktan eğitimde önemli bir yeri olan ÖYS, alanyazında Öğretme Yönetim Sistemleri ve Öğrenim Yönetim Sistemleri olarak da adlandırılmaktadır. Bu çalışmada Öğrenme Yönetim Sistemleri (ÖYS) ifadesi tercih edilmiştir. ÖYS, öğrenci, öğretmen ve yöneticiler için erişim kontrolü, öğrenme içeriğinin sağlanması, tartışılması ve değerlendirilmesi ile ödev sistemi, materyal paylaşımı, ölçme değerlendirme gibi kullanıcı gruplarının organizasyonlarını içeren çevrimiçi öğrenim hizmetlerini düzenleyen bir terim olarak tanımlanmaktadır (Al ve Madran, 2004; Karaman, 2009; Paulsen, 2002; Sezer, 2019). ÖYS iletişim, etkileşim, işbirliği, ders sunumu öğretim etkinliklerinin yönetimi, izlenmesi ve raporlaştırılması gibi eğitimde yapılabilecek tüm uygulamaları üzerinde barındıran özeliklere sahiptir. ÖYS'ler açık kaynak kodlu ve ticari amaçlı olmak üzere iki farklı türde hazırlanmaktadır. Açık kaynak kodlu ÖYS'ler kaynak kodları gizli olmayan ve kullanıcılardan belli bir lisans ücreti talep edilmeyen yazılımlar iken ticari amaçlı ÖYS'ler kaynak kodları gizli ve belli bir lisans ücreti karşılığında kullanma imkânı sunan yazılımlardır (Özbay, 2015).

İnternet tabanlı uzaktan eğitim Türkiye'de ilk kez 1998 yılında Orta Doğu Teknik Üniversitesinde kullanılmış ve o tarihten itibaren teknolojinin gelişmesine paralel olarak kullanım oranı artmıştır. 2017 yılı itibariyle Türkiye'deki 196 üniversiteden 82'si örgün eğitime alternatif olarak lisans, yüksek lisans ve doktora düzeyinde uzaktan eğitim vermektedir (Elitaş, 2017). Dolayısıyla 2017 yılında Türkiye'deki üniversitelerin yaklaşı yarısına yakınının uzaktan eğitim altyapısına sahip olduğu söylenebilir. Bununla birlikte 2020 yılı başında ortaya çıkan Covid-19 salgını nedeniyle uzaktan eğitime geçilmesiyle birlikte tüm üniversiteler internet tabanlı uzaktan eğitim sunan ÖYS'leri kullanmaya başlamıştır. ÖYS'lerden bir tanesi de Kırşehir Ahi Evran Üniversitesinde (KAEÜ) kullanılan Ahi Yeterliğe Dayalı Eğitim Portalı (AYDEP) adı verilen platformdur. AYDEP ÖYS, KAEÜ'de Covid-19 salgını öncesinde lisans düzeyinde örgün eğitimde uluslararası standartlarda yeterlik temelli eğitim-öğretim yapılması, ölçme ve değerlendirmenin standartlaşması ve sürekli iyileştirmeyi esas alan dinamik bir eğitim öğretim yönetimi sağlamayı amaçlayan bir platform olarak geliştirilmiştir. Başlangıçta Eğitim Fakültesi Sınıf Öğretmenleği Programında yüzyüze eğitim yoluyla pilot uygulaması yapılan AYDEP, salgın sebebiyle yapılan uzaktan eğitim faaliyetlerinin de yürütüldüğü bir platform haline dönüşmüştür. Salgının artmas1 sonucunda Nisan 2020 tarihinden itibaren KAEÜ'de ön lisans, lisans ve lisansüstü programlarda tüm teorik dersler AYDEP üzerinden yapılmaktadır. AYDEP ÖYS ve bu sistem üzerinden gerçekleştirilen ders etkinliklerinin süreç bakımından değerlendirilmesi paydaşlara süreç içerisinde yaşananlarla ilgili dönütler sağlayacaktır. 
AYDEP üzerinden yürütülen ders etkinlikleri sürecinin değerlendirmesi için program değerlendirme modellerinden Stufflebeam'e ait CIPP Program Değerlendirme Modeli kullanılmıştır. $\mathrm{Bu}$ program değerlendirme modelinde Bağlam (Context), Girdi (Input), Süreç (Process) ve Ürün (Product) olmak üzere 4 boyut bulunmaktadır. Modelin ilk aşaması olan bağlam boyutu programın planlama aşamasını oluşturmakta ve bir bakıma programın ihtiyaç analizini yapmaktadır. Bu aşamada hedefler, ihtiyaçlar ile çözülecek problemlere odaklanılır ve çevre şartları ortaya konulur. Kaçırılmış fırsatlar, karşılanamayan ihtiyaçlar ve ihtiyaçların karşılanamama sebepleri tespit edilmeye çalışılır. Girdi boyutunda hedeflenen ihtiyaçları karşılamak ve hedeflere ulaşmak için alternatif yaklaşımlar, eylem planlarını uygunluk ve maliyet etkinliği açısından değerlendirir. Süreç boyutunda programda işe koşulması planlanan etkinlikler değerlendirilirken, ürün boyutunda programdan beklenen sonuç ile gerçekleşen sonuç karşılaştırılarak programın etkililiği değerlendirilir (Stufflebeam 2003; Ünal 2011).

CIPP modeli değerlendirmede birçok boyutu ele alan çok yönlü ve kapsamlı bir modelidir. Ünal (2011) bu modelin politikacılar, program veya proje yöneticileri ve bireysel hizmet sağlayıcılar tarafından programın çalışması, geliştirilmesi, taslak program ve projelerin denenmesi, mevcut programın veya hizmetin güçlendirilmesi, ilgililere ve kurumlara hesap verme amaci ile işe koşulabileceğini belirtmektedir. Modelin boyutlarının birbiriyle ilişkisi göz önüne alınarak tüm boyutlarda değerlendirme yapılabileceği gibi, her bir boyut ayrı ayrı değerlendirilebilir (Stufflebeam, 2003). AYDEP'in teknik özelliklerinin değerlendirilmesi ile modelin bağlam ve girdi boyutlarında değerlendirme yapılırken ders etkinliklerinin değerlendirilmesi ile de süreç boyutu değerlendirilmiştir. $\mathrm{Bu}$ değerlendirme çalışması, uygulanan etkinlik veya programın yürütülmesinden sorumlu olanlara dönüt verme gibi yürütme ile ilgili kararların alınmasına yardım etmektedir. Stufflebeam (2003) bu modelin çalışma planındaki veya uygulanmasındaki kusurları belirlemek, süreci yönetmek için geri bildirim sağlamak ve gerçekleşen sürecin kaydını tutmak gibi üç amacı olduğunu vurgulamaktadır. Böylece prograla ilgili tahminde bulunmak, işlemlerle ilgili zorluklarla baş etmek ve planlanan kararları almak için karar vericilere ihtiyaç duydukları bilgiler sağlanır (Ornstein ve Hunkins, 2004).

Bu çalışmada bir ÖYS olan AYDEP'in ve bu sistem üzerinden yürütülen lisansüstü ders etkinliklerinin süreç değerlendirmesini yapmak amaçlanmıştır. Bu amaçla şu sorulara yanıt aranmıştır:

1. Lisansüstü ders etkinliklerinin uzaktan yürütülmesinde kullanılan AYDEP ÖYS'ye ilişkin öğrenci görüşleri nelerdir ve bu görüşler cinsiyete, program ve anabilim dalına göre farklılaşmakta midır?

2. AYDEP üzerinden uzaktan yürütülen lisansüstü ders etkinliklerinin süreç boyutuna ilişkin öğrenci görüşleri nelerdir ve bu görüşler cinsiyete, program ve anabilim dalına göre farklılaşmakta mıdır?

3. Lisansüstü ders etkinliklerinin uzaktan yürütülmesinde kullanılan AYDEP ÖYS'ye ilişkin öğretim elemanı görüşleri nelerdir ve bu görüşler cinsiyet, unvan ve anabilim dalına göre farklılaşmakta midır?

4. AYDEP üzerinden uzaktan yürütülen lisansüstü ders etkinliklerinin süreç boyutuna ilişkin öğretim elemanı görüşleri nelerdir ve bu görüşler cinsiyet, unvan ve anabilim dalına göre farklılaşmakta mıdır?

\section{Yöntem}

$\mathrm{Bu}$ bölümde araştırmanın modeli, evren ve örneklem, veri toplama araçları, verilerin toplanması ve analizi ile araştırma etiğine ilişkin detaylı bilgiye yer verilmiştir.

\section{Araştırma Modeli}

$\mathrm{Bu}$ çalışmada nicel araştırma yöntemlerinden betimsel araştırma (tarama) modeli kullanılmıştır. Karasar (2012) tarama modelini, "geçmişte ya da hâlâ var olan bir durumu, olduğu haliyle betimlemeyen araştırma yaklaşımı" olarak tanımlamaktadır. Tarama çalışmalarında amaç konu ile ilgili mevcut durumun bir fotoğrafını olduğu gibi çekerek betimlemektir (Büyüköztürk Çakmak, Akgün, Karadeniz ve Demirel, 2013). Bu bağlamda betimsel çalışmalar olanın olduğu gibi ortaya 
çıarılmasını amaçlamaktadır. $\mathrm{Bu}$ çalışmada AYDEP üzerinden yürütülen lisansüstü ders etkinliklerinde AYDEP ÖYS ve ders sürecinin mevcut durumuyla ortaya konulması amaçlanmıştır.

\section{Evren ve Örneklem}

Çalışma evreni 2020-2021 akademik yılı güz döneminde KAEÜ Sosyal Bilimler Enstitüsünde lisansüstü öğrenim görmekte olan öğrenciler ve lisansüstü programlarda dersi bulunan öğretim elemanları ile sınırlandırılmıştır. Çalışmada sınırlandırılmış evrenin tümüne ulaşılmaya çalışıldığ i için örneklem seçimine gidilmemiştir. Anket öğrencilere kısa mesaj; öğretim elemanlarına ise e-posta ile gönderilmiştir. Google formlar üzerinden anketi yanıtlayan 171 öğrenci ve 40 öğretim elemanına ait demografik özellikler şöyledir:

Tablo 1

Katılımcllara Ait Demografik Özellikler

\begin{tabular}{|c|c|c|c|c|}
\hline Katılımeı & Demografik Özellikler & Tür & f & $\%$ \\
\hline \multirow{15}{*}{ 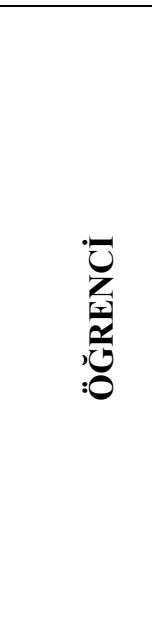 } & \multirow{2}{*}{ Cinsiyet } & Kiz & 87 & 50.90 \\
\hline & & Erkek & 84 & 49.10 \\
\hline & \multirow{2}{*}{ Program Türü } & Yüksek Lisans (YL) & 133 & 77.80 \\
\hline & & Doktora (DR) & 38 & 22.20 \\
\hline & \multirow{11}{*}{ Ana Bilim Dalı } & Antropoloji & 6 & 3.50 \\
\hline & & Eğitim Bilimleri & 27 & 15.80 \\
\hline & & Geleneksel Türk El Sanatları & 10 & 5.80 \\
\hline & & İktisat & 8 & 4.70 \\
\hline & & İşletme & 16 & 9.40 \\
\hline & & Siyaset Bilimi ve Kamu Yönetimi & 12 & 7.00 \\
\hline & & Tarih & 18 & 10.50 \\
\hline & & Temel Eğitim & 17 & 9.90 \\
\hline & & Türk Dili ve Edebiyatı & 22 & 12.90 \\
\hline & & Türkçe ve Sosyal Bilimler Eğitimi & 21 & 12.30 \\
\hline & & Uluslararası İlişkkiler & 14 & 8.20 \\
\hline \multirow{10}{*}{ 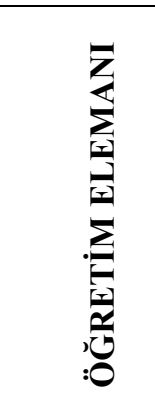 } & \multirow{2}{*}{ Cinsiyet } & Kadın & 14 & 35.00 \\
\hline & & Erkek & 26 & 65.00 \\
\hline & \multirow{4}{*}{ Ünvan } & Profesör & 8 & 20.00 \\
\hline & & Doçent & 14 & 35.00 \\
\hline & & Doktor Öğretim Üyesi & 12 & 30.00 \\
\hline & & Öğretim Görevlisi & 6 & 15.00 \\
\hline & \multirow{4}{*}{$\begin{array}{l}\text { Anabilim Dalının } \\
\text { Bulunduğu Fakülte }\end{array}$} & Eğitim Fakültesi & 14 & 35.00 \\
\hline & & Fen-Edebiyat Fakültesi & 7 & 17.50 \\
\hline & & İdari ve İktisadi Bilimler Fakültesi & 8 & 20.00 \\
\hline & & Güzel Sanatlar Fakültesi & 5 & 12.50 \\
\hline
\end{tabular}

Tablo incelendiğinde katılımcı öğrencilerin cinsiyet oranlarının birbirine oldukça yakın olduğu, öğrencilerin büyük bir çoğunluğunun $(\% 77,8)$ YL öğrencisi olduğu ve KAEÜ Sosyal Bilimler Enstitüsünde yer alan tüm anabilim dalından öğrencilerin katıldıkları görülmektedir. Öğretim elemanı boyutunda erkek katılımcıların oranı (\%65) kadın katılımcılardan (\%35) daha yüksektir. Çalışmaya en çok doçent unvanına (\%35) sahip öğretim elemanları katılmıştır. Ayrıca çalışmaya en yüksek katılım eğitim fakültesinde yer alan anabilim dallarındaki öğretim elemanları tarafından sağlanmıştır.

\section{Veri Toplama Araçları}

Çalışmada veri toplama aracı olarak araştırmacı tarafından hazırlanan AYDEP Değerlendirme ve CIPP Modeli Süreç Değerlendirme olmak üzere iki farklı anket kullanılmıştır. Anketlerin AYDEP ile ilgili maddeleri hazırlanırken AYDEP ÖYS incelenmiş, AYDEP'ten sorumlu uzmanlar ile görüşmeler yapılmış ve Davis'in (1989) Teknoloji Kabul Modeli incelenmiştir. Anketlerin CIPP Modeli değerlendirme kısmı hazırlanırken alanyazın taraması yapılarak bu konudaki çalışmalar incelenmiştir. Belirlenen anket soruları AYDEP sistemi hakkında dönüt sağlayabilecek iki uzmanın 
görüşüne sunulmuştur. Anketlerde ilk etapta 15'i AYDEP Değerlendirme; 21'i CIPP Modeli Süreç Değerlendirme kısmında toplam 36 soru yer almıştır. Uzman görüşleri doğrultusunda son hali verilen anketlerde 17'si AYDEP Değerlendirme Anketi; 18'i CIPP Modeli Süreç Değerlendirme Anketi olmak üzere toplam 35 soru yer almıştır.

\section{Verilerin Toplanması ve Analizi}

Verilerin toplanmasında Google formlardan faydalanılmıștır. Anketin bağlantı adresi katılımcılara gönderilerek araştırmaya katılımları sağlanmıştır. Toplanan veriler öncelikle Excel programına aktarılarak düzenlenmiş ve nicel veri analiz yöntemleri ile uygun bir istatistik programında analiz edilmiştir. Veri analizinde betimsel istatistik ile katılımcıların vermiş olduğu cevapların frekans, yüzdelik dilim ve aritmetik ortalamaları hesaplanmıştır. Öğrenci anketindeki cinsiyet ve öğrenim görülen program türüne göre anlamlı fark olup olmadığını belirlemek için bağımsız örneklemler ttesti; anabilim dalı açısından bir fark olup olmadığının belirlenmesinde Tek Yönlü Varyans Analizi (ANOVA) yapılmıştır. Öğretim elemanı anketinde ise cinsiyet değişkeni için bağımsız örneklemler ttesti; unvan ve görev yaptıkları anabilim dalı değişkeni için ANOVA testi yapılmıştır.

\section{Araştırma Etiği}

Kırşehir Ahi Evran Üniversitesi Sosyal ve Beşeri Bilimleri Etik Kurulu (04/03/2021 tarih ve 2021/01/21 sayı) tarafından "Bir Öğrenme Yönetim Sistemi Olan AYDEP Kapsamında Yürütülen Lisansüstü Derslerin Süreç Değerlendirmesi” konulu araştırmanın bilimsel araştırmalar etiği açısından yapılan değerlendirmesinde kabulüne oy birliğiyle karar verilmiştir.

\section{Bulgular}

Araştırma bulguları 4 başlık altında sunulmuştur. İlk başlık altında AYDEP’e iliş̧in, ikinci başl1kta ders etkinliklerine ilişkin öğrenci görüşlerinden elde edilen bulgular sunulmuştur. Üçüncü başlıkta AYDEP'e ilişkin, dördüncü başlıkta ders etkinlikleri süreç boyutuna ilişkin öğretim elemanlarının görüşlerine ait bulgular sunulmuştur.

\section{AYDEP’in Teknik Özelliklerine İlişkin Öğrenci Bulguları}

AYDEP'in teknik özelliklerinin değerlendirmesine yönelik olarak öğrencilerden elde edilen verilerin aritmetik ortalama, yüzde ve frekansları hesaplanmış, ayrıca cinsiyet, program türü ve anabilim dalı değişkenlerine göre anlamlı farklılık olup olmadığ 1 incelenmiştir. AYDEP'in öğrenciler tarafından değerlendirmesini içeren maddelere ilişkin verilen cevapların aritmetik ortalamaları, frekansları ve yüzdelik dilimleri Tablo 2'de sunulmuştur.

Tablo 2

AYDEP'in Teknik Özelliklerinin Değerlendirilmesine İlişsin Öğrenci Görüşlerinin Aritmetik Ortalama, Frekans ve Yüzdelik Dilimleri

\begin{tabular}{|c|c|c|c|c|c|c|c|}
\hline & & 窇 & 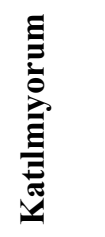 & 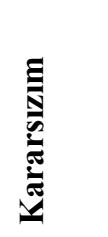 & 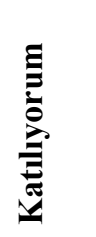 & 递 & \\
\hline & & 1 & 2 & 3 & 4 & 5 & $\overline{\mathrm{X}}$ \\
\hline $\begin{array}{l}\text { 1. AYDEP platformu hakkında yeterince bilgim } \\
\text { vardır. }\end{array}$ & $\begin{array}{l}\mathrm{f} \\
\%\end{array}$ & $\begin{array}{l}2 \\
1.20\end{array}$ & $\begin{array}{l}7 \\
4.10 \\
\end{array}$ & $\begin{array}{l}19 \\
11.10\end{array}$ & $\begin{array}{l}68 \\
39.80 \\
\end{array}$ & $\begin{array}{l}75 \\
43.90\end{array}$ & 4.20 \\
\hline $\begin{array}{l}\text { 2. AYDEP üzerinden yapılan derslerin süresi } \\
\text { yeterlidir. }\end{array}$ & $\begin{array}{l}\mathrm{f} \\
\% \\
\end{array}$ & $\begin{array}{l}11 \\
6.50 \\
\end{array}$ & $\begin{array}{l}20 \\
11.70 \\
\end{array}$ & $\begin{array}{l}43 \\
25.10 \\
\end{array}$ & $\begin{array}{l}50 \\
29.20 \\
\end{array}$ & $\begin{array}{l}47 \\
27.50 \\
\end{array}$ & 3.60 \\
\hline $\begin{array}{l}\text { 3. AYDEP üzerinden yapılan derslere kolayca } \\
\text { ulaşılmaktadır. }\end{array}$ & $\begin{array}{l}\mathrm{f} \\
\% \\
\end{array}$ & $\begin{array}{l}1 \\
0.60 \\
\end{array}$ & $\begin{array}{l}5 \\
2.90 \\
\end{array}$ & $\begin{array}{l}13 \\
7,6 \\
\end{array}$ & $\begin{array}{l}47 \\
27.50 \\
\end{array}$ & $\begin{array}{l}105 \\
61.40 \\
\end{array}$ & 4.50 \\
\hline
\end{tabular}




\begin{tabular}{|c|c|c|c|c|c|c|c|}
\hline 4. AYDEP ara yüzünü kullanmak kolaydır. & $\begin{array}{l}\mathrm{f} \\
\% \\
\end{array}$ & $\begin{array}{l}0 \\
0.00 \\
\end{array}$ & $\begin{array}{l}3 \\
1.80 \\
\end{array}$ & $\begin{array}{l}13 \\
7.70 \\
\end{array}$ & $\begin{array}{l}59 \\
34.50 \\
\end{array}$ & $\begin{array}{l}96 \\
56.10\end{array}$ & 4.50 \\
\hline $\begin{array}{l}\text { 5. AYDEP'in kullanımına yönelik ulaşabileceğim } \\
\text { kilavuzlar bulunmaktadır }\end{array}$ & $\begin{array}{l}\mathrm{f} \\
\%\end{array}$ & $\begin{array}{l}6 \\
3.50 \\
\end{array}$ & 2.90 & $\begin{array}{l}28 \\
16.40 \\
\end{array}$ & $\begin{array}{l}39 \\
22.80\end{array}$ & $\begin{array}{l}93 \\
54.40\end{array}$ & 4.20 \\
\hline $\begin{array}{l}\text { 6. AYDEP derslerin amaçlarını gerçekleştirmeye } \\
\text { katkı sağlayacak nitelikte bir platformdur. }\end{array}$ & $\begin{array}{l}\mathrm{f} \\
\% \\
\end{array}$ & $\begin{array}{l}1 \\
0.60 \\
\end{array}$ & 2.90 & $\begin{array}{l}20 \\
11.70 \\
\end{array}$ & 40.40 & $\begin{array}{l}76 \\
44.40\end{array}$ & 4.30 \\
\hline $\begin{array}{l}\text { 7. AYDEP sistemi üzerinden yürütülen dersler } \\
\text { akademik gelişimimi destekleyici niteliktedir. }\end{array}$ & $\begin{array}{l}\mathrm{f} \\
\%\end{array}$ & $\begin{array}{l}3 \\
1.80\end{array}$ & $\begin{array}{l}4 \\
2.30\end{array}$ & $\begin{array}{l}20 \\
11.70\end{array}$ & $\begin{array}{l}70 \\
40.90\end{array}$ & $\begin{array}{l}74 \\
43.30\end{array}$ & 4.20 \\
\hline $\begin{array}{l}\begin{array}{l}\text { 8. AYDEP. uygulama açısından işlevsel bir } \\
\text { platformdur }\end{array} \\
\text { plater }\end{array}$ & $\begin{array}{l}\mathrm{f} \\
\% \\
\end{array}$ & $\begin{array}{l}0 \\
0.00 \\
\end{array}$ & $\begin{array}{l}2 \\
1.20 \\
\end{array}$ & $\begin{array}{l}20 \\
11.70 \\
\end{array}$ & $\begin{array}{l}76 \\
44.40 \\
\end{array}$ & $\begin{array}{l}73 \\
42.70 \\
\end{array}$ & 4.30 \\
\hline $\begin{array}{l}\text { *9. AYDEP üzerinden yapılan çevrimiçi dersler } \\
\text { öğrenmeyi zorlaştırmaktadır. }\end{array}$ & $\begin{array}{l}\mathrm{f} \\
\% \\
\end{array}$ & $\begin{array}{l}70 \\
40.90 \\
\end{array}$ & $\begin{array}{l}58 \\
33.90 \\
\end{array}$ & $\begin{array}{l}16 \\
9.40 \\
\end{array}$ & $\begin{array}{l}13 \\
7.60 \\
\end{array}$ & $\begin{array}{l}14 \\
8.20 \\
\end{array}$ & 4.00 \\
\hline $\begin{array}{l}\text { 10. AYDEP üzerinden yapılan çevrimiçi dersler } \\
\text { öğrenmeyi destekleyici niteliktedir. }\end{array}$ & $\begin{array}{l}\mathrm{f} \\
\% \\
\end{array}$ & $\begin{array}{l}0 \\
0.00 \\
\end{array}$ & $\begin{array}{ll}6 \\
3.50 \\
\end{array}$ & $\begin{array}{l}16 \\
9.40 \\
\end{array}$ & $\begin{array}{l}56 \\
32.70 \\
\end{array}$ & $\begin{array}{l}93 \\
54.40\end{array}$ & 4.40 \\
\hline $\begin{array}{l}\text { 11. AYDEP üzerinden yapılan dersleri tekrar } \\
\text { izleyebilme imkânı vardır. }\end{array}$ & $\begin{array}{l}\mathrm{f} \\
\% \\
\end{array}$ & $\begin{array}{l}3 \\
1.80 \\
\end{array}$ & $\begin{array}{l}4 \\
2.30 \\
\end{array}$ & $\begin{array}{l}23 \\
13.50 \\
\end{array}$ & $\begin{array}{l}30 \\
17.50 \\
\end{array}$ & $\begin{array}{l}111 \\
64.90\end{array}$ & 4.40 \\
\hline $\begin{array}{l}\text { *12. AYDEP sisteminin kullanımında altyapı } \\
\text { sorunları (server vb.) sıklıkla yaşanmaktadır. }\end{array}$ & $\begin{array}{l}\mathrm{f} \\
\% \\
\end{array}$ & $\begin{array}{l}44 \\
25.70 \\
\end{array}$ & $\begin{array}{l}53 \\
31.00 \\
\end{array}$ & $\begin{array}{l}33 \\
19.30 \\
\end{array}$ & $\begin{array}{l}20 \\
11.70 \\
\end{array}$ & $\begin{array}{l}21 \\
12.30 \\
\end{array}$ & 3.50 \\
\hline $\begin{array}{l}\text { 13. AYDEP üzerinden yapılan derslerde yaşanan } \\
\text { sorunlara uygun çözümler bulunmaktadır. }\end{array}$ & $\begin{array}{l}\mathrm{f} \\
\% \\
\end{array}$ & $\begin{array}{ll}1 \\
0.60 \\
\end{array}$ & $\begin{array}{l}5 \\
2.90 \\
\end{array}$ & $\begin{array}{l}30 \\
17.50 \\
\end{array}$ & $\begin{array}{l}63 \\
36.80 \\
\end{array}$ & $\begin{array}{l}72 \\
42.10 \\
\end{array}$ & 4.20 \\
\hline $\begin{array}{l}\text { 14. AYDEP platformunda derslerle ilgili önemli } \\
\text { duyurular (sinav /ödev teslim tarihleri) yapılmaktadır. }\end{array}$ & $\begin{array}{l}\mathrm{f} \\
\%\end{array}$ & $\begin{array}{l}0 \\
0.00\end{array}$ & $\begin{array}{l}2 \\
1.20\end{array}$ & $\begin{array}{l}27 \\
4.10\end{array}$ & $\begin{array}{l}28 \\
16.40\end{array}$ & $\begin{array}{l}134 \\
78.40\end{array}$ & 4.70 \\
\hline $\begin{array}{l}\text { 15. AYDEP platformu yüklenen ödevlere öğretim } \\
\text { elemanlarınca dönüt verme imkânı sunmaktadır. }\end{array}$ & $\begin{array}{l}\mathrm{f} \\
\%\end{array}$ & $\begin{array}{l}0 \\
0.00\end{array}$ & $\begin{array}{l}5 \\
2.90\end{array}$ & $\begin{array}{l}10 \\
5.80\end{array}$ & 17.50 & $\begin{array}{l}126 \\
73.70\end{array}$ & 4.60 \\
\hline $\begin{array}{l}\text { 16. AYDEP sisteminin ekran paylaşımı ve ekran } \\
\text { kullanımı işlevseldir. }\end{array}$ & $\begin{array}{l}\mathrm{f} \\
\% \\
\end{array}$ & $\begin{array}{l}8 \\
4.70 \\
\end{array}$ & $\begin{array}{l}16 \\
9.40 \\
\end{array}$ & $\begin{array}{l}43 \\
25.10 \\
\end{array}$ & $\begin{array}{l}50 \\
29.20 \\
\end{array}$ & $\begin{array}{l}54 \\
31.60 \\
\end{array}$ & 3.70 \\
\hline $\begin{array}{l}\text { 17. AYDEP'in uzaktan eğitim sürecinde faydalı } \\
\text { olduğunu düşünüyorum. }\end{array}$ & $\begin{array}{l}\mathrm{f} \\
\% \\
\end{array}$ & $\begin{array}{l}3 \\
1.80 \\
\end{array}$ & $\begin{array}{l}2 \\
1.20 \\
\end{array}$ & $\begin{array}{l}14 \\
8.20 \\
\end{array}$ & $\begin{array}{l}37 \\
21.60 \\
\end{array}$ & $\begin{array}{l}115 \\
67.30\end{array}$ & 4.50 \\
\hline & & & \multicolumn{4}{|c|}{ Ortalama } & 4.20 \\
\hline
\end{tabular}

*Ters çevrilerek kodlanan olumsuz maddeler

Öğrenci anketinde AYDEP'in teknik özeliklerine ilişkin yanıtların genel ortalaması 4,20'dir. Bu bölümdeki iki olumsuz madde ters çevrilerek kodlanmıştır. Yapılan analiz sonucu elde edilen bulgular incelendiğinde tüm maddelerin olumlu nitelikte olduğu görülmektedir. Bu sonuçlara göre lisansüstü öğrencilerin AYDEP ÖYS hakkında yüksek düzeyde olumlu düşüncelere sahip olduğu söylenebilir. Bulgu ve yorumların daha anlaşı1ır olması için, anket maddeleri "Algılanan Fayda (AF)", "Algılanan Kolaylık (AK)" ve "Sistem Özellikleri ve İyileştirmeleri (SÖI)" olmak üzere üç başlık altında toplanmıştır. AF ve AK başlıkları Davis'in (1989) Teknoloji Kabul Modelinden alınmıștır. SÖİ başlığı ise araştırmacı tarafindan oluşturulmuştur. AF grubunda sekiz $(2,6,7,8,9,10,16$ ve 17); AK grubunda iki (3 ve 4); SÖİ grubunda yedi madde $(1,5,11,12,13,14$ ve 15) bulunmaktadır.

AF grubundaki maddelerin tamamının aritmetik ortalaması katılıyorum düzeyi ve üzerindedir. Ders süreleri, sistemin ekran kullanımı ve paylaşımına ilişkin maddeler en düşük ortalamaya sahiptir. Katılımcıların ders sürelerinin yeterliliği ve sistemin ekran paylaşımı/kullanımı konusunda kararsızım düzeyine yakın oldukları söylenebilir. AK grubundaki iki maddenin (3 ve 4) aritmetik ortalamalarının aynı ve tamamen katılıyorum düzeyinde $(\bar{X}=4,50)$ olması katılımcılara göre AYDEP sistemini kullanmanın kolay olduğunu göstermektedir. SÖİ grubunda yer alan 12. maddenin (AYDEP sisteminin kullanımında altyapı sorunları (server vb.) sıklıkla yaşanmaktadır) ortalaması $(\bar{X}=3,50)$ katılıyorum düzeyinde olmakla birlikte kararsızım düzeyine yakındır. Bu bulguya göre katılımcıların AYDEP sistemini kullanırken bazı altyapısal sorunlarla karşılaşıtıları söylenebilir. Öte yandan diğer maddelerin aritmetik ortalamasının tamamen katılıyorum düzeyinde olması katılımcıların AYDEP'in sistem özellikleri ve iyileştirmeleri hakkında olumlu düşüncelere sahip olduğunu göstermektedir.

AYDEP'in teknik özelliklerine ilişkin öğrenci görüşlerinde cinsiyet değişkenine göre farklılık olup olmadığını tespit etmek için bağımsız örneklemler T-testi yapılmıştır. Cinsiyet değiş̧kenine göre anlamlı farklılık tespit edilen maddeler Tablo 3 'te yer almaktadır. 
Tablo 3

Cinsiyet Değişkenine İlişkin t-Testi Sonucu (AYDEP-Öğrenci)

\begin{tabular}{lllccccc}
\hline Madde & Grup & $\mathbf{N}$ & $\overline{\mathbf{X}}$ & $\mathbf{S}$ & sd & t & P \\
\hline 5. AYDEP'in kullanımına yönelik ulaşabileceğim & Erkek & 84 & 4.39 & 0.86 & 169 & 2.18 & .030 \\
kılavuzlar bulunmaktadır. & Kız & 87 & 4.04 & 1.18 & & & \\
\hline
\end{tabular}

*Anlamlı farklılık bulunmayan maddeler için Tablo 2'yi inceleyebilirsiniz.

Cinsiyet değişkenine göre bir maddede (M5) anlamlı farklılık bulunmuştur ( $\mathrm{p}=.030<.05)$. Bu maddeye her iki grupta katılmakla birlikte erkek öğrencilerin aritmetik ortalamalası daha yüksek olduğu için erkek öğrenciler lehine anlamlı farkl11ık olduğu söylenebilir.

AYDEP'in teknik özelliklerine ilişkin öğrenci görüşlerinde program türü değiş̧kenine göre farklılık olup olmadığını tespit etmek için bağımsız örneklemler T-testi yapılmıştır. Program türü değişkenine göre anlamlı farklılık tespit edilen maddeler Tablo 4'te yer almaktadır.

Tablo 4

Program Türü Değişkenine İlişkin t-Testi Sonucu (AYDEP-Öğrenci)

\begin{tabular}{|c|c|c|c|c|c|c|c|}
\hline Madde & Grup & $\mathbf{N}$ & $\overline{\mathbf{X}}$ & $\mathbf{S}$ & sd & $\mathbf{t}$ & $\mathbf{p}$ \\
\hline \multirow{2}{*}{$\begin{array}{l}\text { 3. AYDEP üzerinden yapılan derslere kolayca } \\
\text { ulaşılmaktadır. }\end{array}$} & YL & 133 & 4.41 & 0.84 & 79.20 & -2.01 & .048 \\
\hline & DR & 38 & 4.66 & 0.63 & & & \\
\hline \multirow{2}{*}{$\begin{array}{l}\text { 6. AYDEP derslerin amaçlarını gerçekleştirmeye } \\
\text { katkı sağlayacak nitelikte bir platformdur. }\end{array}$} & YL & 133 & 4.17 & 0.84 & 169 & -2.37 & .019 \\
\hline & DR & 38 & 4.53 & 0.69 & & & \\
\hline \multirow{2}{*}{$\begin{array}{l}\text { 8. AYDEP uygulama açısından işlevsel bir } \\
\text { platformdur }\end{array}$} & YL & 133 & 4.22 & 0.74 & 169 & -2.37 & .019 \\
\hline & DR & 38 & 4.53 & 0.56 & & & \\
\hline \multirow{2}{*}{$\begin{array}{l}\text { 10. AYDEP üzerinden yapılan çevrimiçi dersler } \\
\text { ögrenmeyi destekleyici niteliktedir. }\end{array}$} & YL & 133 & 4.31 & 0.85 & 107 & -2.97 & .004 \\
\hline & DR & 38 & 4.63 & 0.49 & & & \\
\hline \multirow{2}{*}{$\begin{array}{l}\text { 11. AYDEP üzerinden yapılan dersleri öğrencilerin } \\
\text { tekrar izleyebilme imkânı vardır. }\end{array}$} & YL & 133 & 4.35 & 0.97 & 76.40 & -2.11 & .037 \\
\hline & DR & 38 & 4.66 & 0.75 & & & \\
\hline \multirow{2}{*}{$\begin{array}{l}\text { 17. AYDEP'in uzaktan eğitim sürecinde faydalı } \\
\text { olduğunu düşünüyorum. }\end{array}$} & YL & 133 & 4.45 & 0.90 & 110 & -2.53 & .013 \\
\hline & DR & 38 & 4.74 & 0.50 & & & \\
\hline
\end{tabular}

*Anlamlı farklılık bulunmayan maddeler için Tablo 2'yi inceleyebilirsiniz.

Program türü değişkenine göre 17 maddeden iki tanesinde anlamlı fark bulunmuştur. Anlamlı fark olan tüm maddelerde doktora grubunun aritmetik ortalamalarının yüksek olması farkın doktora grubu lehine olduğu göstermektedir. İlgili maddeler incelendiğinde doktora öğrencileri yüksek lisans öğrencilerine göre AYDEP sistemini daha kolay, işlevsel ve faydalı buldukları anlaşılmaktadır.

AYDEP'e ilişkin öğrenci görüşlerinde anabilim dalı değişkenine göre anlamlı anlamlı bir fark olup olmadığını belirlemek için yapılan ANOVA testine ilişkin analizler Tablo 5'te sunulmuştur.

Tablo 5

Anabilim Dalı Değişkenine İlişkin ANOVA Testi Sonucu (AYDEP-Öğrenci)

\begin{tabular}{lccccc}
\hline Varyansın Kaynağı & Kareler Toplamı & sd & Kareler Ortalaması & F & p \\
\hline Gruplar arası & 2.150 & 10 & .21 & .64 & .772 \\
\hline Gruplar içi & 53.21 & 160 & .33 & & \\
\hline Toplam & 55.36 & 170 & & & \\
\hline
\end{tabular}

11 anabilim dalında gruplar arası ve gruplar içi anlamlı fark olmadığ için $(\mathrm{p}=, 772>, 05)$ değişkenlerin kendi arasındaki dağılımının incelenmesinde kullanılan post-hoc testleri yapılmamıştır.

\section{CIPP Modeli Süreç Boyutuna İlişkin Öğrenci Bulguları}

AYDEP üzerinden yürütülen ders etkinlikleri CIPP modeli süreç boyutuna göre değerlendirilmiştir. Bu boyuta ait verilerin ortalama, yüzde ve frekansları ile cinsiyet, program türü ve anabilim dalına göre anlamlı fark olup olmadığı belirlenmiştir. Ders etkinliklerinin değerlendirmesini içeren maddelerin aritmetik ortalama, frekans ve yüzdelik dilimleri Tablo 6'da yer almaktadır. 
Tablo 6

Ders Etkinliklerinin CIPP Modeli Süreç Boyutuna Göre Değerlendirmesine İlişkin Aritmetik Ortalama, Frekans ve Yüzdelik Dilimler

\begin{tabular}{|c|c|c|c|c|c|c|c|}
\hline & & 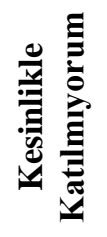 & E & 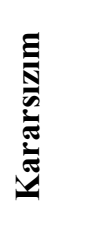 & 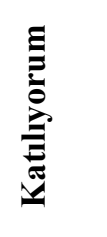 & 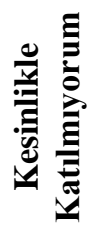 & \\
\hline & & 1 & 2 & 3 & 4 & 5 & $\overline{\mathrm{X}}$ \\
\hline 1. AYDEP üzerinden yapılan derslerdeki etkinlikler & $\mathrm{f}$ & 3 & 3 & 20 & 51 & 94 & \\
\hline derslere aktif olarak katılmamı sağlamaktadır. & $\%$ & 1.80 & 1.80 & 11.70 & 29.80 & 55.00 & 4.30 \\
\hline 2. AYDEP üzerinden yapılan dersler öğrenci & f & 3 & 7 & 20 & 49 & 92 & \\
\hline merkezli olarak yürütülmektedir. & $\%$ & 1.80 & 4.10 & 11.70 & 28.70 & 53.80 & 4.30 \\
\hline 3. AYDEP üzerinden yapılan derslerde bireysel & $\mathrm{f}$ & 3 & 10 & 29 & 44 & 85 & \\
\hline $\begin{array}{l}\text { öğrenmelere olanak sağlayacak etkinliklere yer } \\
\text { verilmektedir. }\end{array}$ & $\%$ & 1.80 & 5.80 & 17.0 & 25.70 & 49.70 & 4.20 \\
\hline 4. AYDEP üzerinden yapılan derslerde işbirlikçi & $\mathrm{f}$ & 5 & 20 & 50 & 62 & 34 & 360 \\
\hline etkinlikler yapılmaktadır. & $\%$ & 2.90 & 11.70 & 29.20 & 36.30 & 19.90 & 3.00 \\
\hline 5. AYDEP üzerinden yapılan ders etkinliklerinde & $\mathrm{f}$ & 13 & 23 & 57 & 45 & 33 & 3 \\
\hline grup çalışmalarına yer verilmektedir. & $\%$ & 7.60 & 13.50 & 33.30 & 26.30 & 19.30 & .40 \\
\hline 6. AYDEP üzerinden yapılan derslerdeki etkinlikler & $\mathrm{f}$ & 5 & 8 & 28 & 63 & 67 & 400 \\
\hline derse olan motivasyonumu ve ilgimi arttırmaktadır. & $\%$ & 2.90 & 4.70 & 16.40 & 36.80 & 39.20 & 4.00 \\
\hline 7. AYDEP üzerinden yapılan dersler problem çözme & f & 3 & 12 & 32 & 71 & 53 & \\
\hline $\begin{array}{l}\text { ve eleştirel düşünme gibi üst düzey becerilerimi } \\
\text { geliştirmektedir. }\end{array}$ & $\%$ & 1.80 & 7.00 & 18.70 & 41.50 & 31.00 & 3.90 \\
\hline 8. AYDEP üzerinden yapılan derslerde paylaşılan & $\mathrm{f}$ & 3 & 4 & 21 & 73 & 70 & \\
\hline $\begin{array}{l}\text { görsel ve işitsel materyaller öğrenmemi } \\
\text { kolaylaştırmaktadır. }\end{array}$ & $\%$ & 1.80 & 2.30 & 12.30 & 42.70 & 40.90 & 4.20 \\
\hline 9. AYDEP üzerinden yapılan derslerde & f & 5 & 3 & 13 & 67 & 83 & \\
\hline $\begin{array}{l}\text { öğrendiklerimi hayata geçirecek araştırma ödevleri } \\
\text { verilir. }\end{array}$ & $\%$ & 2.90 & 1.80 & 7.60 & 39.20 & 48.50 & 4.40 \\
\hline 10. AYDEP üzerinden yapılan derslerde verilen & $\mathrm{f}$ & 3 & 7 & 13 & 41 & 107 & \\
\hline $\begin{array}{l}\text { ödevlere/araştırmalara öğretim elemanları yeterli } \\
\text { düzeyde rehberlik ederler. }\end{array}$ & $\%$ & 1.80 & 4.10 & 7.60 & 24.00 & 62.60 & 4.40 \\
\hline 11. AYDEP üzerinden yapılan derslerde yapılan & f & 2 & 6 & 17 & 38 & 108 & \\
\hline $\begin{array}{l}\text { ödevlere/araştırmalara uygun süre içerisinde dönüt } \\
\text { verilmektedir. }\end{array}$ & $\%$ & 1.20 & 3.50 & 9.90 & 22.20 & 63.20 & 4.40 \\
\hline 12. AYDEP üzerinden yapılan derslerde ilgi ve & $\mathrm{f}$ & 4 & 6 & 15 & 41 & 105 & 4.40 \\
\hline yeteneklerime uygun ödevler verilmektedir. & $\%$ & 2.30 & 3.50 & 8.80 & 24.00 & 61.40 & \\
\hline 13. AYDEP üzerinden yapılan derslerde verilen & $\mathrm{f}$ & 3 & 7 & 10 & 43 & 108 & 440 \\
\hline ödevler için yeterli süre tanınmaktadır. & $\%$ & 1.80 & 4.10 & 5.80 & 25.10 & 63.20 & 4.40 \\
\hline 14. AYDEP üzerinden yapılan derslerde & $\mathrm{f}$ & 7 & 5 & 28 & 59 & 72 & \\
\hline $\begin{array}{l}\text { gerçekleştirilen etkinlikler tartışarak ve karşıl1kli fikir } \\
\text { alışverişinde bulunarak öğrenmemi sağlamaktadır. }\end{array}$ & $\%$ & 4.10 & 2.90 & 16.40 & 34.50 & 42.10 & 4.10 \\
\hline 15. AYDEP üzerinden yapılan derslerde süreç & $\mathrm{f}$ & 6 & 10 & 25 & 72 & 58 & 00 \\
\hline değerlendirilmesi yapılmaktadır & $\%$ & 3.50 & 5.80 & 14.60 & 42.10 & 33.90 & \\
\hline 16. AYDEP üzerinden yapılan derslerde farklı & f & 10 & 23 & 41 & 62 & 35 & 350 \\
\hline yöntem ve teknikler kullanılmaktadır & $\%$ & 5.80 & 13.50 & 24.0 & 36.30 & 20.50 & 3.50 \\
\hline *17. AYDEP üzerinden yapılan derslerde zaman & $\mathrm{f}$ & 21 & 15 & 21 & 47 & 67 & 0 \\
\hline zaman ders düzeni bozulmaktadır. & $\%$ & 12.30 & 8.80 & 12.30 & 27.50 & 39.20 & 3.10 \\
\hline 18. AYDEP üzerinden yapılan derslerde öğretici- & f & 3 & 2 & 16 & 51 & 99 & \\
\hline $\begin{array}{l}\text { öğrenen ve öğrenen-öğrenen arasında iki yönlü } \\
\text { iletişim sağlanmaktadır. }\end{array}$ & $\%$ & 1.80 & 1.20 & 9.40 & 29.80 & 57.90 & 4.40 \\
\hline *Ters kodlanan maddeler & & & & & $\mathrm{O}$ & & 4.00 \\
\hline
\end{tabular}


Öğrencilerin ders etkinliklerine ilişkin yanıtlarının genel ortalaması 4,00'dır. Bu bağlamda CIPP modeli süreç boyutu ölçütlerine göre öğrencilerin ders etkinlikleri hakkında olumlu düşüncelere sahip olduğu söylenebilir. Tabloda en düşük aritmetik ortalamaya sahip 3 madde (4, 5 ve 16) derslerde kullanılan farklı yöntem ve tekniklerle ilgilidir. Dolayısıyla derslerde farklı yöntem ve tekniklerin kullanılması hususunda öğrencilerin düşüncelerinde net bir farklılık olmadığ 1 yorumu yapılabilir. Öte yandan en yüksek aritmetik ortalamaya $(\bar{X}=4,40)$ sahip maddeler $(9,10,11,12$ ve 13$)$ ödevler yani öğrencilerin iş yükü ile ilgilidir. Öğrencilerin ödevlerin uygunluğu, süresi ve yapılan rehberlik ile verilen dönütlere ilişkin olumlu düşüncelere sahip olduğu söylenebilir. En yüksek ortalamaya sahip bir diğer madde (M18) ise iki yönlü iletişimle ilgilidir. Dolayısıyla derslerde öğretici-öğrenen ve öğrenenöğrenen arasındaki iletişim düzeyinin yüksek olduğu söylenebilir. Diğer maddelerin aritmetik ortalaması yaklaşık olarak "Katılıyorum" düzeyinde olduğu için katılımcıların işlenen derslerin aktif katılım, öğrenci merkezli olması, ilgi çekici olması ve bireysel öğrenmelere imkân sağlanması ve sürekli olarak değerlendirilmesi konusunda olumlu düşüncelere sahip olduğu yorumu yapılabilir.

Ders etkinliklerine ilişkin öğrenci görüşlerinde cinsiyet değişkenine göre farklılık olup olmadığını tespit etmek için bağımsız örneklemler T-testi yapılmıştır. Cinsiyet değişkenine göre anlamlı farklılık tespit edilen maddeler Tablo 7'de yer almaktadır.

Tablo 7

Cinsiyet Değişkenine İlişkin t-Testi Sonucu (Süreç-Öğrenci)

\begin{tabular}{|c|c|c|c|c|c|c|c|}
\hline Madde & Gr & $\mathbf{N}$ & $\overline{\mathbf{X}}$ & $\mathbf{S}$ & sd & $\mathbf{t}$ & $\mathbf{p}$ \\
\hline \multirow{2}{*}{$\begin{array}{l}\text { 8. AYDEP üzerinden yapılan derslerde paylaşılan görsel ve } \\
\text { işitsel materyaller öğrenmemi kolaylaştırmaktadır. }\end{array}$} & & 84 & 4.32 & 0.79 & \multirow[t]{2}{*}{169} & \multirow[t]{2}{*}{2.00} & \multirow[t]{2}{*}{.046} \\
\hline & $\mathrm{K}_{12}$ & 87 & 4.06 & 0.92 & & & \\
\hline \multirow{2}{*}{$\begin{array}{l}\text { 13. AYDEP üzerinden yapılan derslerde verilen ödevler için } \\
\text { yeterli süre tanınmaktadır. }\end{array}$} & & & 4.6 & 0.68 & \multirow[t]{2}{*}{146} & \multirow[t]{2}{*}{2.43} & \multirow[t]{2}{*}{.016} \\
\hline & $\mathrm{K}_{1 \mathrm{z}}$ & 87 & 4.28 & 1.06 & & & \\
\hline
\end{tabular}

*Anlamlı farklılık bulunmayan maddeler için Tablo 6'yı inceleyebilirsiniz.

Cinsiyet değişkenine göre 18 maddeden iki tanesinde anlamlı farklılık bulunmuştur. Anlamlı farkl111k bulunan maddelere her iki grupta katılmakla birlikte gruplar arasında anlamlı farkl111k bulunmuştur $(\mathrm{p}=, 046 /, 016<, 05)$. Aritmetik ortalamalar incelendiğinde erkek öğrencilerin aritmetik ortalaması yüksek olduğu için anlamlı farklılığın erkek öğrenci grubu lehine olduğu söylenebilir.

Ders etkinliklerine ilişkin öğrenci görüşlerinde program türü değişkenine göre farklılık olup olmadığını tespit etmek için bağımsız örneklemler T-testi yapılmıştır. Program türü değişkenine göre anlamlı farklilık tespit edilen maddeler Tablo 8'de sunulmuştur.

Tablo 8

Program Türü Değişkenine İlişkin t-Testi Sonucu (Süreç-Öğrenci)

\begin{tabular}{|c|c|c|c|c|c|c|c|}
\hline Madde & Grup & $\mathbf{N}$ & $\overline{\mathbf{X}}$ & $\mathbf{S}$ & sd & $\mathbf{t}$ & p \\
\hline \multirow{2}{*}{$\begin{array}{l}\text { 1. AYDEP üzerinden yapılan derslerdeki etkinlikler, } \\
\text { derslere aktif olarak katılmamı sağlamaktadır. }\end{array}$} & YL & 133 & 4.26 & 0.91 & 169 & -2.29 & .023 \\
\hline & DR & 38 & 4.63 & 0.71 & & & \\
\hline \multirow{2}{*}{$\begin{array}{l}\text { 3. AYDEP üzerinden yapılan derslerde bireysel } \\
\text { öğrenmelere olanak sağlayacak etkinliklere yer } \\
\text { verilmektedir. }\end{array}$} & YL & 133 & 4.08 & 1.04 & 169 & -2.00 & .047 \\
\hline & DR & 38 & 4.45 & 0.89 & & & \\
\hline \multirow{2}{*}{$\begin{array}{l}\text { 12. AYDEP üzerinden yapilan derslerde ilgi ve } \\
\text { yeteneklerime uygun ödevler verilmektedir. }\end{array}$} & YL & 133 & 4.32 & 1.01 & 89 & -2.25 & .027 \\
\hline & DR & 38 & 4.63 & 0.67 & & & \\
\hline \multirow{2}{*}{$\begin{array}{l}\text { 13. AYDEP üzerinden yapılan derslerde verilen ödevler } \\
\text { için yeterli süre tanınmaktadır. }\end{array}$} & YL & 133 & 4.37 & 0.97 & 103 & -2.51 & .014 \\
\hline & DR & 38 & 4.68 & 0.57 & & & \\
\hline \multirow{2}{*}{$\begin{array}{l}\text { 14. AYDEP üzerinden yapılan derslerde gerçekleştirilen } \\
\text { etkinlikler, tartışarak ve karşılıklı fikir alışverişinde } \\
\text { bulunarak öğrenmemi sağlamaktadır. }\end{array}$} & YL & 133 & 3.99 & 1.04 & 169 & -1.99 & .048 \\
\hline & DR & 38 & 4.37 & 0.97 & & & \\
\hline \multirow{2}{*}{$\begin{array}{l}\text { 15. AYDEP üzerinden yapılan derslerde süreç } \\
\text { değerlendirilmesi yapılmaktadır }\end{array}$} & YL & 133 & 3.89 & 1.03 & 169 & -2.02 & .045 \\
\hline & DR & 38 & 4.26 & 0.95 & & & \\
\hline \multirow{2}{*}{$\begin{array}{l}\text { 18. AYDEP üzerinden yapılan derslerde öğretici-öğrenen } \\
\text { ve öğrenen-öğrenen arasında iki yönlü iletişim } \\
\text { sağlanmaktadır. }\end{array}$} & YL & 133 & 4.33 & 0.89 & 84 & -2.79 & .006 \\
\hline & DR & 38 & 4.68 & 0.62 & & & \\
\hline
\end{tabular}

*Anlamlı farklılık bulunmayan maddeler için Tablo 6'yı inceleyebilirsiniz. 
Program türüne göre yedi maddede anlamlı fark bulunmuştur. Anlamlı farklılık bulunan tüm maddelerde doktora grubunun aritmetik ortalamalarının yüksek olması anlamlı farklılığın doktora grubu lehine olduğu göstermektedir. Tablodaki maddeler incelendiğinde doktora öğrencilerinin yüksek lisans öğrencilerine göre derslere katılım, bireysel öğrenme, ödevlerin uygunluğu, ders içi iletişim ve ders sürecinin değerlendirilmesi gibi konularda olumlu düşüncelere sahip olduğu söylenebilir.

Ders etkinliklerine ilișkin öğrenci görüșlerinde anabilim dalı değișkenine göre anlamlı bir fark olup olmadığını tespit etmek için yapılan ANOVA testine ilişkin analizler Tablo 9'da sunulmuştur.

Tablo 9

Anabilim Dalı Değişkenine İlişkin ANOVA Testi Sonucu (Süreç-Öğrenci)

\begin{tabular}{lccccc}
\hline Varyansın Kaynağı & Kareler Toplamı & sd & Kareler Ortalaması & F & p \\
\hline Gruplar arası & 3.55 & 10 & .35 & .60 & .810 \\
Gruplar içi & 94.29 & 160 & .58 & & \\
Toplam & 97.84 & 170 & & & \\
\hline
\end{tabular}

11 anabilim dalında gruplar arası ve gruplar içi anlamlı farklılık olmadığından $(\mathrm{p}=, 810>, 05)$ değişkenlerin kendi arasındaki dağılımının incelenmesinde kullanılan post-hoc testleri yapılmamıştır.

\section{AYDEP'in Teknik Özelliklerine İlișkin Öğretim Elemanı Bulguları}

AYDEP'e ilişkin verilerin aritmetik ortama, yüzde ve frekansları tespit edilmiş ve bunun yanı sıra cinsiyet, program türü ve anabilim dalı değişkenlerine göre anlamlı farklılık olup olmadığını tespit edilerek tablo halinde sunulmuştur. Öğretim elemanlarının AYDEP'i değerlendirmesini içeren maddelerin aritmetik ortalama, frekans ve yüzdelik dilimler Tablo 10'da yer almaktadır.

Tablo 10

AYDEP'in Teknik Özelliklerinin Değerlendirilmesine İlişkin Öğretim Elemanı Görüşlerinin Aritmetik Ortalama, Frekans ve Yüzdelik Dilimleri

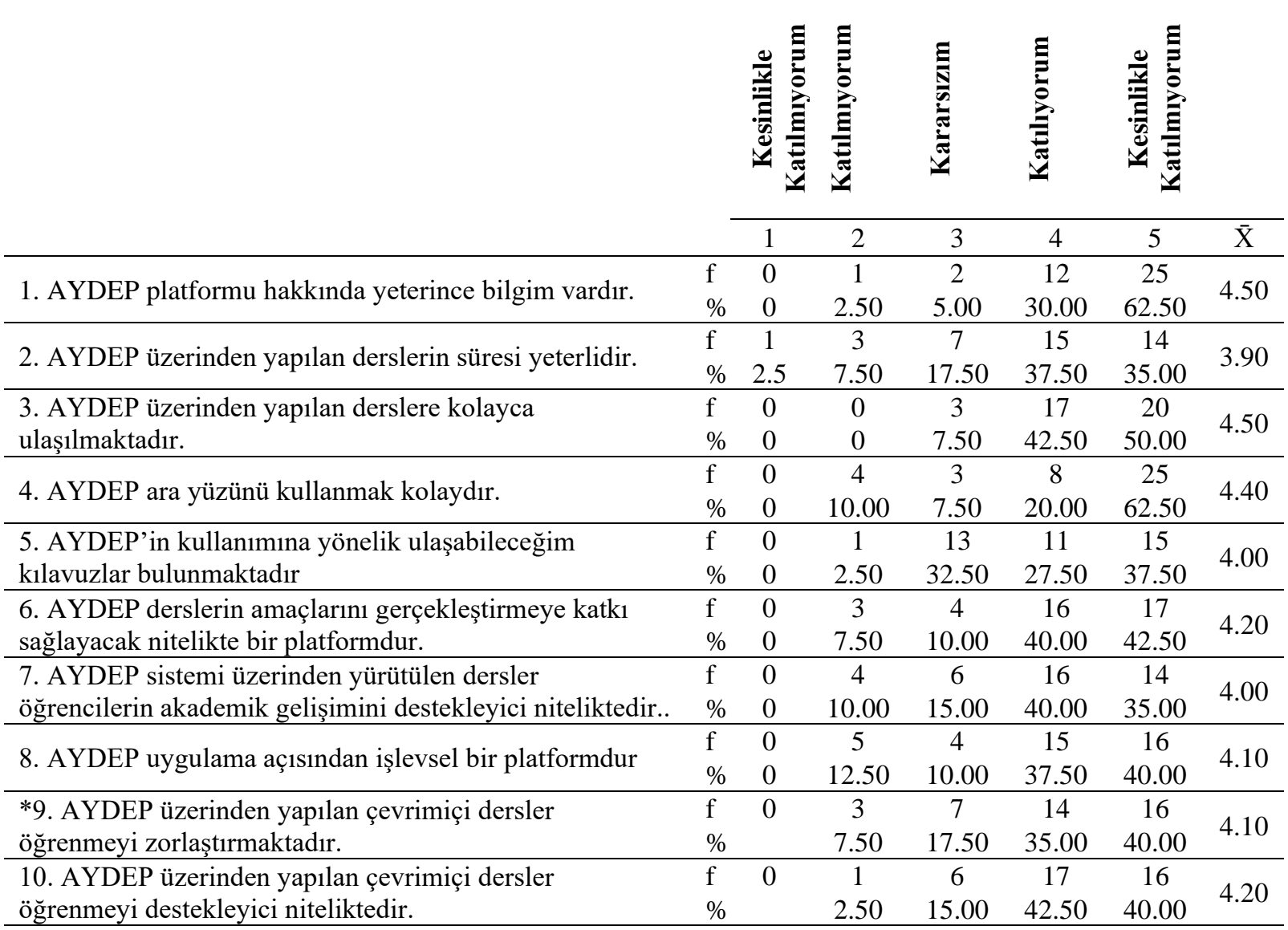




\begin{tabular}{|c|c|c|c|c|c|c|c|}
\hline $\begin{array}{l}\text { 11. AYDEP üzerinden yapılan dersleri öğrencilerin tekrar } \\
\text { izleyebilme imkânı vardır. }\end{array}$ & $\begin{array}{l}\mathrm{f} \\
\%\end{array}$ & $\begin{array}{l}0 \\
0\end{array}$ & $\begin{array}{l}0 \\
0\end{array}$ & $\begin{array}{c}3 \\
7.50 \\
\end{array}$ & $\begin{array}{c}11 \\
27.50\end{array}$ & $\begin{array}{c}26 \\
65.00\end{array}$ & 4.60 \\
\hline $\begin{array}{l}\text { *12. AYDEP sisteminin kullanımında altyapısal sorunlar } \\
\text { (server vb.) sıklıkla yaşanmaktadır. }\end{array}$ & $\begin{array}{l}\mathrm{f} \\
\%\end{array}$ & $\begin{array}{c}6 \\
15.0\end{array}$ & $\begin{array}{c}4 \\
10.00\end{array}$ & $\begin{array}{c}10 \\
26.00\end{array}$ & $\begin{array}{c}10 \\
25.00\end{array}$ & $\begin{array}{c}10 \\
25.00\end{array}$ & 3.40 \\
\hline $\begin{array}{l}\text { 13. AYDEP üzerinden yapılan derslerde yaşanan } \\
\text { sorunlara uygun çözümler bulunmaktadır. }\end{array}$ & $\begin{array}{l}\mathrm{f} \\
\%\end{array}$ & $\begin{array}{c}1 \\
2.50\end{array}$ & $\begin{array}{c}3 \\
7.50\end{array}$ & $\begin{array}{c}11 \\
27.50\end{array}$ & $\begin{array}{c}11 \\
27.50\end{array}$ & $\begin{array}{c}14 \\
35.00\end{array}$ & 3.90 \\
\hline $\begin{array}{l}\text { 14. AYDEP platformunda derslerle ilgili önemli duyurular } \\
\text { (sınav/ödev teslim tarihleri) yapılmaktadır. }\end{array}$ & $\begin{array}{l}\mathrm{f} \\
\%\end{array}$ & $\begin{array}{l}0 \\
0\end{array}$ & $\begin{array}{l}0 \\
0\end{array}$ & $\begin{array}{c}2 \\
5.00\end{array}$ & $\begin{array}{c}15 \\
37.50\end{array}$ & $\begin{array}{c}23 \\
57.50\end{array}$ & 4.60 \\
\hline $\begin{array}{l}\text { 15. AYDEP platformu yüklenen ödevlere öğretim } \\
\text { elemanlarınca dönüt verme imkânı sunmaktadır. }\end{array}$ & $\begin{array}{l}\mathrm{f} \\
\%\end{array}$ & $\begin{array}{l}0 \\
0\end{array}$ & $\begin{array}{c}1 \\
2.50\end{array}$ & $\begin{array}{c}3 \\
7.50\end{array}$ & $\begin{array}{c}14 \\
35.00\end{array}$ & $\begin{array}{c}22 \\
55.00\end{array}$ & 4.50 \\
\hline $\begin{array}{l}\text { 16. AYDEP'in sisteminin ekran paylaşımı ve ekran } \\
\text { kullanımı işlevseldir. }\end{array}$ & $\begin{array}{l}\mathrm{f} \\
\% \\
\end{array}$ & $\begin{array}{c}1 \\
2.50 \\
\end{array}$ & $\begin{array}{c}2 \\
5.00 \\
\end{array}$ & $\begin{array}{c}3 \\
7.50 \\
\end{array}$ & $\begin{array}{c}15 \\
37.50 \\
\end{array}$ & $\begin{array}{c}19 \\
47.50 \\
\end{array}$ & 4.20 \\
\hline $\begin{array}{l}\text { 17. AYDEP'in uzaktan eğitim sürecinde faydalı olduğunu } \\
\text { düşünüyorum. }\end{array}$ & $\begin{array}{l}\mathrm{f} \\
\%\end{array}$ & $\begin{array}{l}0 \\
0\end{array}$ & $\begin{array}{l}0 \\
0\end{array}$ & $\begin{array}{c}5 \\
12.50 \\
\end{array}$ & $\begin{array}{c}11 \\
27.50\end{array}$ & $\begin{array}{c}24 \\
60.00 \\
\end{array}$ & 4.50 \\
\hline
\end{tabular}

*Ters kodlanan maddeler

Öğretim elemanlarının AYDEP'in teknik özelliklerine ilişkin yanıtlarının genel ortalaması öğrencilerin ortalamasıyla aynıdır $(\bar{X}=4,20)$. Öğretim elemanlarının da öğrenciler gibi AYDEP'in teknik özelikleri hakkında yüksek düzeyde olumlu düşüncelere sahip olduğu söylenebilir. AF ile ilgili maddelerin $(2,6,7,8,9,10,16$. ve 17.) aritmetik ortalamasının katıllyorum düzeyi ve üzerinde olmas1 katılımcıların AYDEP'i faydalı bulduğunu göstermektedir. Ders sürelerinin yeterliğine ilişkin ikinci maddenin en düşük aritmetik ortalamaya $(\overline{\mathrm{X}}=3,90)$ sahip olması dikkat çekmektedir. AK grubundaki iki maddenin (3. ve 4.) aritmetik ortalaması aynı ve oldukça yüksektir $(\overline{\mathrm{X}}=4,50 / 4,40)$. Dolayısıyla AYDEP kullanımının öğretim elemanlarına göre kolay olduğu söylenebilir. SÖİ grubundaki $(1,5,11$, $12,13,14$. ve 15 . maddeler) madde 12 (AYDEP sisteminin kullanımında altyapı sorunları sıklıkla yaşanmaktadır) ve madde 13 (AYDEP üzerinden yapılan derslerde yaşanan sorunlara uygun çözümler bulunmaktadır) gruptaki en düşük ortalamalara $(\bar{X}=3,40 / 3,90)$ sahiptir. Buna göre katılımcıların AYDEP'i kullanırken altyapısal sorunlarla karşılaştıkları ve sistemde yaşanan sorunlara ilişkin uygun çözümler bulunduğu konusunda katılıyorum düzeyinin altında görüş belirttikleri söylenebilir. Diğer maddelerin ortalamasının katılıyorum düzeyi ve üstünde olması katılımcıların AYDEP'in sistem özellikleri ve iyileştirmeleri hakkında olumlu düşüncelere sahip olduğunu göstermektedir.

AYDEP'in teknik özelliklerine ilişkin öğretim elemanı görüşlerinde cinsiyet değişkenine göre farklılık olup olmadığını tespit etmek için yapılan bağımsız örneklemler T-testi yapılmıştır. Cinsiyet değişkenine göre anlamlı farklılık tespit edilen madde Tablo 11'de sunulmuştur.

Tablo 11

Cinsiyet Değişkenine Illişkin t-Testi Sonucu (AYDEP-Öğretim Elemanı)

\begin{tabular}{lccccccc}
\hline Madde & Grup & $\mathbf{N}$ & $\overline{\mathbf{X}}$ & $\mathbf{S}$ & $\mathbf{s d}$ & $\mathbf{t}$ & $\mathbf{p}$ \\
\hline \multirow{2}{*}{ 4. AYDEP ara yüzünü kullanmak kolaydır. } & Erkek & 26 & 4.15 & 1.16 & 38 & -2.16 & .037 \\
& Kadın & 14 & 4.71 & 0.47 & & & \\
\hline
\end{tabular}

*Anlamlı farklılık bulunmayan maddeler için Tablo 10’u inceleyebilirsiniz.

Cinsiyet değişkenine bir maddede anlamlı farklılık bulunmuştur $(\mathrm{p}=, 037<, 05)$. Kadın öğretim elemanlarının aritmetik ortalaması yüksek olduğu için anlamlı farklılı̆̆ın kadın öğretim elemanları lehine olduğu söylenebilir.

AYDEP'in teknik özelliklerine ilişkin öğretim elemanı görüşlerinde unvan ve anabilim dalına göre bir fark olup olmadığının tespiti için yapılan ANOVA testi sonuçları Tablo 12'de sunulmuştur. 
Tablo 12

Unvan ve Anabilim Dalı Değişkenine İlişkin ANOVA Testi Sonucu (AYDEP-Öğretim Elemanı)

\begin{tabular}{|c|c|c|c|c|c|c|}
\hline \multirow{4}{*}{ 紊 } & Varyansın Kaynağı & Kareler Toplamı & sd & Kareler Ortalaması & $\mathbf{F}$ & $\mathbf{p}$ \\
\hline & Gruplar aras1 & .38 & 3 & .12 & .68 & .567 \\
\hline & Gruplar içi & 6.70 & 36 & .18 & & \\
\hline & Toplam & 7.08 & 39 & & & \\
\hline \multirow{4}{*}{ 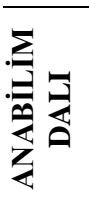 } & Varyansın Kaynağı & Kareler Toplamı & sd & Kareler Ortalaması & $\mathbf{F}$ & $\mathbf{p}$ \\
\hline & Gruplar arası & .85 & 4 & .21 & 1.19 & .331 \\
\hline & Gruplar içi & 6.23 & 35 & .17 & & \\
\hline & Toplam & 7.08 & 39 & & & \\
\hline
\end{tabular}

Unvan ve anabilim dalında gruplar arası ve gruplar içi fark olmadığı için $(\mathrm{p}=, 567 /, 331>, 05)$ değişkenlerin kendi içindeki dağılımlarının incelenmesi için kullanılan post-hoc testleri yapılmamıştır.

\section{CIPP Modeli Süreç Boyutuna İlișkin Öğretim Elemanı Bulguları}

Öğretim elemanlarının ders etkinliklerinin değerlendirmesini içeren maddelere ilişkin verdiği cevaplara göre hesaplanan aritmetik ortalama, frekans ve yüzdelik dilimler Tablo 13'de sunulmuştur.

Tablo 13

Ders Etkinliklerinin CIPP Modeli Süreç Boyutuna Göre Değerlendirmesine İlişkin Aritmetik Ortalama, Frekans ve Yüzdelik Dilimler

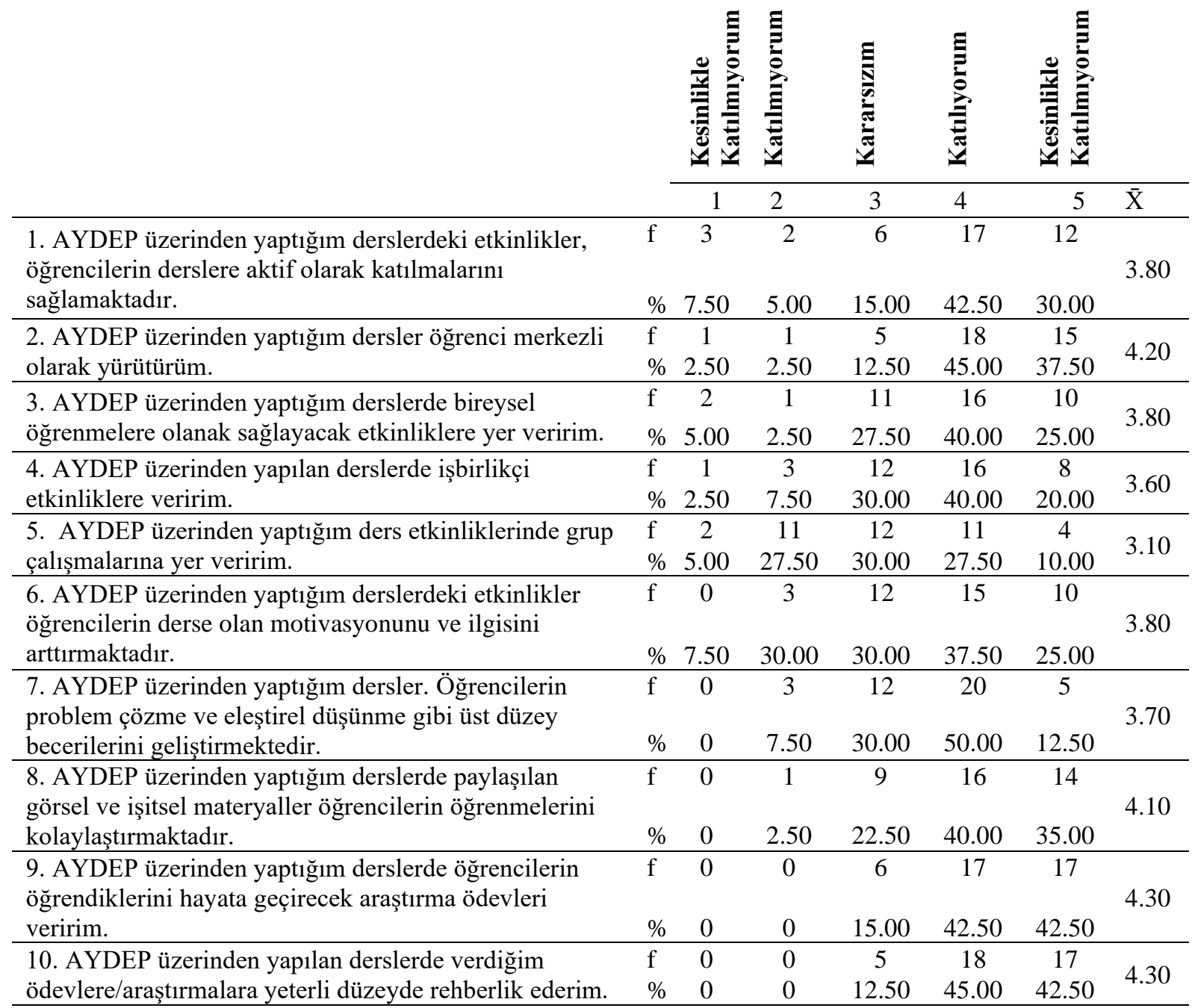




\begin{tabular}{|c|c|c|c|c|c|c|c|}
\hline \multirow{2}{*}{$\begin{array}{l}\text { 11. AYDEP üzerinden yapılan derslerde verdiğim } \\
\text { odevlere/araştırmalara uygun süre içerisinde dönüt } \\
\text { veririm. }\end{array}$} & $\mathrm{f}$ & & 0 & 4 & 20 & 15 & \multirow[t]{2}{*}{4.20} \\
\hline & $\%$ & 2.50 & 0 & 10.00 & 50.00 & 37.50 & \\
\hline \multirow{2}{*}{$\begin{array}{l}\text { 12. AYDEP üzerinden yapilan derslerde öğrencilerin ilgi } \\
\text { ve yeteneklerine uygun ödevler veririm. }\end{array}$} & $\mathrm{f}$ & 0 & 2 & 3 & 18 & 17 & \multirow{2}{*}{4.30} \\
\hline & $\%$ & 0 & 5.00 & 7.50 & 45.00 & 42.50 & \\
\hline \multirow{2}{*}{$\begin{array}{l}\text { 13. AYDEP üzerinden yapılan derslerde verdiğim } \\
\text { ödevler için yeterli süre tanırım. }\end{array}$} & $f$ & 0 & 1 & 1 & 10 & 28 & \multirow{2}{*}{4.70} \\
\hline & $\%$ & 0 & 2.50 & 2.50 & 25.00 & 70.00 & \\
\hline \multirow{2}{*}{$\begin{array}{l}\text { 14. AYDEP üzerinden yapılan derslerde } \\
\text { gerçekleştirdiğim etkinlikler, öğrencilerin tartışarak ve } \\
\text { karşlıkl fikir alışverişinde bulunarak öğrenmelerini } \\
\text { sağlamaktadır. }\end{array}$} & $\mathrm{f}$ & 1 & 5 & 8 & 15 & 11 & \multirow[b]{2}{*}{3.80} \\
\hline & $\%$ & 2.50 & 12.50 & 20.00 & 37.50 & 27.50 & \\
\hline \multirow{2}{*}{$\begin{array}{l}\text { 15. AYDEP üzerinden yaptı̆̆ım derslerde süreci } \\
\text { değerlendiririm. }\end{array}$} & $\mathrm{f}$ & 0 & 0 & 6 & 15 & 19 & \multirow{2}{*}{4.40} \\
\hline & $\%$ & 0 & 0 & 15.00 & 37.50 & 47.50 & \\
\hline \multirow{2}{*}{$\begin{array}{l}\text { 16. AYDEP üzerinden yaptı̆ı̆ım derslerde farklı yöntem } \\
\text { ve teknikler kullanırım. }\end{array}$} & $f$ & 0 & 4 & 12 & 17 & 7 & \multirow{2}{*}{3.70} \\
\hline & $\%$ & 0 & 10.00 & 30.00 & 42.50 & 17.50 & \\
\hline \multirow{2}{*}{$\begin{array}{l}\text { *17. AYDEP üzerinden yaptı̆̆ım derslerde zaman } \\
\text { zaman ders düzeni bozulmaktadır. }\end{array}$} & $\mathrm{f}$ & 1 & 10 & 5 & & 13 & \multirow{2}{*}{3.70} \\
\hline & $\%$ & 2.50 & 25.00 & 12.50 & 27.50 & 32.50 & \\
\hline \multirow{2}{*}{$\begin{array}{l}\text { 18. AYDEP üzerinden yapılan derslerde öğretici- } \\
\text { öğrenen ve öğrenen-öğrenen arasında iki yönlü iletişim } \\
\text { sağlanmaktadır. }\end{array}$} & & 1 & 8 & 6 & 13 & 12 & \multirow{2}{*}{3.70} \\
\hline & $\%$ & 2.50 & 20.00 & 15.00 & 32.50 & 30.00 & \\
\hline *Ters kodlanan maddeler & & & & & & & 3.90 \\
\hline
\end{tabular}

Öğretim elemanlarının ders etkinliklerine ilişkin yanıtlarının genel ortalaması 3.90'dır. Öğretim elemanlarının CIPP modeli süreç boyutu değerlendirme ölçütlerine göre ders etkinlikleri hakkındaki düşüncelerinin katılıyorum düzeyine yakın olduğu söylenebilir. Tabloda "Katılıyorum" düzeyinde aritmetik ortalamaya sahip 9 madde $(1,3,4,6,7,14,16,17$ ve 18) bulunmaktadır. Bu maddeler derslere aktif katılım, derslerde kullanılan yöntem ve teknikler, ders içi iletişim ile ilgilidir. Öğretim elemanların bu hususlarda düşünceleri katıllyorum düzeyinde olmakla birlikte aritmetik ortalamaların 4,00 altında olması sebebiyle düşüncelerinde net bir ayrım olmadığ1 söylenebilir. 5 . madde (AYDEP üzerinden yaptığım ders etkinliklerinde grup çalışmalarına yer veririm) tablodaki en düşük aritmetik ortalamaya $(\overline{\mathrm{X}}=3,10)$ sahiptir ve kararsızım düzeyindeki tek maddedir. Aritmetik ortalaması katılıyorum düzeyinden yüksek olan maddelerin $(2,8,9,10,11,12,13$. ve 15.) öğrenci merkezli eğitim, materyaller, ödevler ve ders sürecinin devamlı değerlendirilmesi ile ilgili olduğu görülmektedir. Bu bağlamda öğretim elemanları derslerin öğrenci merkezli olarak yürütüldügünü, öğrencilere fayda sağlayacak uygun ödevler verildiğini, uygun sürede dönüt verilerek rehberlik yapıldığını ve ders sürecinin devamlı değerlendirdiklerini düşünmektedirler.

Ders etkinliklerine ilişkin öğretim elemanı görüşlerinde cinsiyet değişkenine göre farklılık olup olmadığını tespit etmek için bağımsız örneklemler T-testi yapılmıştır. Cinsiyet değişkenine göre anlamlı farklilık tespit edilen maddeler Tablo 14'te sunulmuştur.

Tablo 14

Cinsiyet Değişkenine Göre t-Testi Sonucu (Süreç-Öğretim Elemanı)

\begin{tabular}{|c|c|c|c|c|c|c|c|}
\hline \multirow{3}{*}{$\begin{array}{l}\text { Madde } \\
\text { 6. AYDEP üzerinden yaptığım derslerdeki etkinlikler, } \\
\text { öğrencilerin derse olan motivasyonunu ve ilgisini } \\
\text { arttırmaktadır. }\end{array}$} & Grup & $\mathbf{N}$ & $\overline{\mathbf{X}}$ & S & sd & $\mathbf{t}$ & $\mathbf{p}$ \\
\hline & Erkek & 26 & 3.58 & 0.90 & \multirow{2}{*}{38} & \multirow{2}{*}{-2.21} & \multirow{2}{*}{.033} \\
\hline & Kadın & 14 & 4.21 & 0.80 & & & \\
\hline \multirow{2}{*}{$\begin{array}{l}\text { 7. AYDEP üzerinden yaptığım dersler, öğrencilerin problem } \\
\text { çözme ve eleştirel düş̧ünme gibi üst düzey becerilerini } \\
\text { geliştirmektedir. }\end{array}$} & Erkek & 26 & 3.50 & 0.86 & \multirow[t]{2}{*}{38} & \multirow[t]{2}{*}{-2.22} & \multirow[t]{2}{*}{.032 } \\
\hline & Kadın & 14 & 4.00 & 0.55 & & & \\
\hline
\end{tabular}

Cinsiyet değişkenine göre iki maddede anlamlı farklılık bulunmuştur. Bu maddelere her iki grupta katılmakla birlikte kadın öğretim elemanları lehine anlamlı farklılık vardır ( $\mathrm{p}=, 033 /, 032<, 05)$.

Ders etkinliklerine ilişkin öğretim elemanı görüşlerinde unvan ve anabilim dalına göre anlamlı bir fark olup olmadığını belirlemek için yapılan ANOVA testi sonuçları Tablo 15'te sunulmuştur. 
Tablo 15

Unvan ve Anabilim Dalı Değişkenine İlişkin ANOVA Testi Sonucu (Süreç-Öğretim Elemanı)

\begin{tabular}{llccccc}
\hline \multicolumn{1}{c}{ Varyansın Kaynağı } & Kareler Toplamı & sd & Kareler Ortalaması & F & p \\
\cline { 2 - 8 } & Gruplar arası & .09 & 3 & .03 & .12 & .944 \\
Gruplar içi & 9.41 & 36 & .26 & & \\
Toplam & 9.51 & 39 & & & \\
\hline & Varyansın Kaynağı & Kareler Toplamı & sd & Kareler Ortalaması & F & $\mathbf{p}$ \\
\cline { 2 - 8 } & Gruplar arası & 1.45 & 4 & .36 & 1.58 & .201 \\
Gruplar içi & 8.06 & 35 & .23 & & \\
Toplam & 9.51 & 39 & & & \\
\hline
\end{tabular}

Unvan ve anabilim dalı değişkenlerine göre gruplar arası ve gruplar içi anlamlı fark olmadığından ( $\mathrm{p}=, 944 /, 201>, 05)$ değişkenlerin kendi arasındaki dağılımlarının incelenmesinde kullanılan post-hoc testleri yapılmamıştır.

\section{Sonuç, Tartışma ve Öneriler}

AYDEP ÖYS Değerlendirme Anketinden elde edilen bulgulara göre öğrenci ve öğretim elemanlarının verdiği yanıtların ortalaması "Tamamen Katılıyorum" düzeyindendir. Bu bağlamda anketteki maddelerin AF, AK ve SÖİ başlıkları altında gruplandırıldığı göz önüne alınılacak olursa katılımcıların AYDEP sistemi hakkında yeterli düzeyde bilgi sahibi oldukları, sistemi kolay ve faydalı buldukları ayrıca sistemin teknik özellikleri konusunda memnun oldukları sonucu çıkarılabilir.

Davis (1989) AF ve AK'1 bireylerin teknoloji kullanımı konusunda düşünceleri belirleyen önemli etkenler olduğunu belirtmektedir. AF'a ilişkin sekiz maddeden öğrenci grubunda altısının; öğretim elemanı grubunda yedisinin olumlu düzeyde olması katılımcıların AYDEP'i faydalı ve işlevsel buldukları sonucu ortaya koymaktadır. Öte yandan ders süresi, ekran paylaşımı ve kullanımına ilişkin maddelerin nispeten düşük ortalamaları dikkat çekmektedir. AK grubundaki iki maddenin hem öğrenci hem de öğretim elemanı grubunda aritmetik ortalamasının tamamen katılıyorum düzeyinde olması sistemin katılımcılar tarafından kullanımının kolay bulunduğunun bir göstergesidir. AYDEP'in katılımeılarca faydalı ve kolay bulunması anketin genel puanını olumlu yönde etkilemiştir. Alanyazında bu sonuca benzer bulgular içeren çalışmalar bulunmaktadır (Aldemir, 2017; Efiloğlu Kurt, 2015; Eren ve Kaya, 2017; Lee, Cheung ve Chen, 2005; Solak, 2012). Yıldırır ve Kaplan (2019) çalışmalarında algılanan fayda ve algılanan kolaylığın mobil teknoloji kullanımlarını olumlu etkilediği sonucuna ulaşılmıştır. İlgili çalışmada katılımcılar kolay anlaşılabilir, işlevsel ve kendilerine fayda sağlayabilecek uygulamaları tercih ettiklerini belirtmişlerdir. Benzer şekilde Eren ve Kaya (2017) uzaktan eğitim sisteminin kolay ve kullanışlı olmasının kullanıcıların sistem hakkındaki düşüncelerini olumlu etkilediğini ifade etmektedir. Efiloğlu Kurt (2015) uzaktan eğitimde kullanılan sisteme erişimin kolay olması, anlaşılırlığı, öğreniminin zor olmaması algılanan faydayı ve sistem kullanımını olumlu etkilediği sonucuna ulaşmıştır. Yabancı alanyazın incelendiğinde Sun vd. (2008) algılanan kolaylığının öğrencilerin sistemle ilgili düşüncelerini belirleyen etmenler arasında yer aldığı sonucuna ulaşmıştır. Lee vd. (2005) algılanan faydanın kullanıcı düşüncelerini olumlu etkilediği sonucunu ulaşılırken, algılanan kolaylığın kullanıcı düşünceleri üzerinde bir etkisi olmadığını belirtmektedir.

ÖYS'lerde teknik özellikler, teknik sorunlara karşı geliştirilen çözümler katılımcıların ÖYS ile ilgili düşüncelerini etkilemektedir. Bu çalışmada SÖİ grubundaki altı maddeden öğrenci grubunda sadece bir; öğretim elemanı grubunda iki madde katılıyorum düzeyinin altında ortalamaya sahipken diğer maddeler katılıyorum düzeyinin üstünde ortalamaya sahip olması katılımcıların sistemin kalitesinden memnun oldukları sonucunu ortaya koymaktadır. Bu sonucu destekler nitelikte sistem kalitesinin kullanıcılarının sistem ile ilgili düşüncelerini olumlu etkilediğini belirten çalışmalar bulunmaktadır (Çelik, 2018; Lin, 2007; Freeze, Alshare, Lane ve Wen, 2010; Ramayah, Ahmad ve Lo, 2010; Şimşek, İslim ve Öztürk, 2019). Efiloğlu Kurt (2015) ise çalışmasında sistemin teknik özelliklerinin, sistem hakkındaki memnuniyeti destekler hipotezinin reddedildiği sonucuna ulaşmıştır. 
AYDEP anketinde cinsiyet değişkenine göre her iki grupta sadece bir maddede anlamlı farklılık bulunmuştur. Öğrenci grubunda "AYDEP'in kullanımına yönelik ulaşabileceğim kılavuzlar bulunmaktadır" maddesinde erkek öğrenciler; öğretim elemanı grubunda ise "AYDEP arayüzünü kullanmak kolaydır" maddesinde kadın öğretim elemanları lehine anlamlı farklılık vardır. Bu bağlamda cinsiyet değişkenine göre sistem hakkındaki görüşlerin farklılaşmadığı sonucuna ulaşılmıştır. İşbulan (2015) öğretmen adayları ile yaptığı çalışmasında da cinsiyet değişkenine göre anlamlı farklılık bulunmadığı tespit edilmiştir. AYDEP anketinde öğrencilerin öğrenim gördükleri program türü değişkenine altı maddede doktora öğrencileri lehine anlamlı farklılık bulunmuştur. Anlamlı farklılık bulunan maddeler incelendiğinde doktora öğrencilerinin yüksek lisans öğrencilerine göre AYDEP sistemini daha kolay, işlevsel ve faydalı buldukları sonucuna ulaşılmıştır.

CIPP Modeli Süreç Değerlendirme Anketinden elde edilen bulgulara göre öğrencilerin ve öğretim elemanlarının verdiği yanıtların ortalaması "Katılıyorum" düzeyindedir. Bu bağlamda her iki grubun ders etkinlikleri hakkında olumlu düşüncelere sahip olduğu sonucuna ulaşılmaktadır. Alanyazın incelendiğinde bu araştırmadan elde edilen sonucu destekleyen çalışmalar olduğu görülmektedir (Cansu, 2010; Karataş, 2007; Orhan, 2016; Özer, 2011; Ünal, 2011). Cansu'nun (2010) bir e-sertifika programını değerlendirdiği çalışmasında katılımcıların büyük çoğunluğu e-öğrenme ortamlarının öğrenmeyi kolaylaştırdığını düşünmektedir. Orhan (2016) uzaktan eğitimle yürütülen İngilizce derslerinin değerlendirmesini yaptığı çalışmasında öğrencilerin en çok süreç boyutundan memnun olduklarını ortaya koymuştur. Ünal'ın (2011) çalışmasında ise süreç boyutu ile ilgili tüm maddelere katılımcılar tarafindan olumlu cevaplar verildiği görülmüştür. Karataş (2007) ve Özer'in (2011) çalışmasında öğrenci ve öğretmenlerin süreç boyutuyla ilgili puanları yüksek çıkmıştır.

Öğrenci anketinde en düşük aritmetik ortalamaya sahip üç maddenin derslerde kullanılan farklı yöntem ve tekniklere ilişkin olduğu sonucuna ulaşılmıştır. Öğrencilerin bu konuda kararsıza daha yakın oldukları söylenebilir. Öğretim elemanlarının ise derslerde kullanılan yöntem ve teknikler konusunun yanı sıra ders içi iletişim konusunda da katılıyorum düzeyinin altında fikir belirttikleri sonucuna ulaşılmıştır. Bu çalışmanın sonuçlarına paralel olarak Tokmak, Baturay ve Fadde (2013) çalışmalarında öğrencilerin derslerde kullanılan yöntem ve teknikler konusunda memnun olmadıklarını ortaya koymuştur. Tunç'un (2010) çalışması ise bu çalışmanın sonuçları ile farklıdır. Söz konusu çalışmada süreç boyutunda kullanılan öğretim yöntem ve teknikleri ile kullanılan materyallerin hem öğrenci hem de İngilizce dersi okutmanlarını tatmin ettiği sonucuna ulaşılmıştır.

Çalışmada her iki grupta en yüksek ortalamaya sahip maddelerin ödevler yani öğrencilerin iş yükü ile ilgili olduğu sonucuna ulaşılmıştır. Katılımcıların ödevlerin uygunluğu, süresi ve yapılan rehberlik ile verilen dönütlere ilişkin olumlu düşüncelere sahip olduğu söylenebilir. Karataş (2007) çalışmasında katılımcıların pekiştirici nitelikli ödevler verilmesi konusunda olumlu bir görüsse sahip oldukları sonucuna ulaşmıştır. Öğrenci anketinde yüksek ortalamaya sahip maddelerden bir tanesi de AYDEP'in iki yönlü iletişim sağlama düzeyini inceleyen 18. maddedir. Bu madde öğrenci anketinde tamamen katılıyorum düzeyinde iken öğretim elemanı anketinde bu madde katılıyorum düzeyindedir. Dolayısıyla her iki grupta AYDEP'in iki yönü iletişim sağladığını düşünmekle birlikte bu oranın öğrencilerde daha yüksek olduğu anlaşılmaktadır. Bu çalışmanın sonucuyla çelişen İşman ve Dabaj (2005) çalışmalarında öğrencilerin önemli bir kısmının uzaktan eğitimde etkileşim ve iletişim sorunu yaşadıklarını sonucunu bulmuşlardır. Ancak bu çalışma AYDEP'in bir ÖYS olarak hem öğrenci hem de öğretim elemanlarına göre öğrenme-öğretme sürecinde iki yönlü iletişim sağladığı sonucunu ortaya koymaktadır. Bu sonucun ortaya çıkmasında çalışmanın lisans ve önlisans sınıflarına nispeten sınıf mevcutlarının daha az olduğu lisansüstü öğrenim verilen sınıflarda gerçekleştirilmesinin etkili olduğu düşünülmektedir. Diğer maddelerin aritmetik ortalaması incelendiğinde yaklaşık olarak "Katılıyorum" düzeyinde olduğu sonucuna ulaşılmıştır. Bu bağlamda katılımcıların işlenen derslerin aktif katılım, öğrenci merkezli olması, ilgi çekici olması ve bireysel öğrenmelere imkân sağlanması, sürekli olarak değerlendirilmesi konusunda olumlu düşüncelere sahip olduğu yorumu yapılabilir. $\mathrm{Bu}$ çalışmanın sonuçlarına paralel olarak Yarmohammadian, Ahmadi, Sadrian ve Fooladvand (2011) çalışmalarında öğrencilerin ders etkinliklerinden genel itibariyle memnun oldukları sonucuna ulaşılmıştır. Kudryavtseva (2014) farklı yöntem ve tekniklerin kullanılması, görüntü ve ses aktarımı sağlayan 
iletişim araçları vasıtasıyla öğrenen-öğreten veya öğrenen-öğrenen arasında iletişim sağlanmasının öğrencilerin güdülenmelerini arttırarak uzaktan eğitimde başarısının arttığı vurgulanmaktadır.

Ders etkinliklerinin cinsiyete göre anlamlı düzeyde farklılı̆̆ıyla ilgili analizlerde öğrenci ve öğretim elemanı gruplarında sadece iki maddede farklılık bulunmuştur. Erkek öğrenciler lehine materyallerin öğrenimi kolaylaştırması ve ödev sürelerinin yeterliği konusunda anlamlı fark vardır. Bu bağlamda erkek öğrencilerin derslerin anlaşılırlığı konusunda kızlara göre görsel işitsel materyallere daha çok ihtiyaç duyduğu ve ödev süreleri ile ilgili sorun yaşamadıkları sonucuna ulaşılabilir. Ders etkinliklerinin öğrenci motivasyonunu arttırıcı nitelikte olması ve derslerin üst düzey becerileri arttırıcı nitelikte olması hususunda kadın öğretim elemanları lehine anlamlı farklılıklar tespit edilmiștir. $\mathrm{Bu}$ bağlamda kadın öğretim elemanları, derslerinin öğrenci motivasyonunu arttırdığını ve öğrencilerin üst düzey becerilerini geliştirdiğini düşünmektedirler. Ders etkinlikleri öğrencilerin program türü değişkenine göre incelendiğinde doktora grubu öğrencilerinin derslere aktif katılım, bireysel öğrenme, ödevlerin ilgi ve yeteneklerine uygunluğu, derslerdeki iletişim ve ders sürecinin değerlendirilmesi ile ilgili yüksek lisans öğrencilere göre olumlu düşüncelere sahip olduğu sonucuna ulaşılmıştır. Diğer taraftan öğrencilerin öğrenim gördükleri anabilim dalı, öğretim elamanlarının unvanları ve görev yaptıkları bölüm değişkenlerine göre anlamlı bir farklılı̆̆a sahip olmadığı sonucuna ulaşılmıştır.

Bir ÖYS olan AYDEP ve bu sistem üzerinden yürütülen lisansüstü ders etkinliklerinin incelendiği bu çalışmada, katılımcıların AYDEP'ten ve ders etkinliklerinden genel olarak memnun oldukları sonucuna ulaşılmıştır. Çalışma sonuçlarından hareketle şu öneriler getirilebilir. Sisteminin altyapısı (server vb.) geliştirilebilir, ekran paylaşımı ve kullanım özelliği gözden geçirilebilir. AYDEP üzerinden yürütülen ders etkinliklerinde farklı yöntem ve teknikler kullanılabilir. Çeşitli teknoloji kabul modellerine ilișkin teoriler incelenerek hazırlanan bir ölçme aracı ile ÖYS'ler değerlendirilebilir. CIPP değerlendirme modelinin tüm boyutları veya farklı değerlendirme modelleri ile değerlendirme yapılabilir. Çalışma daha geniş bir örneklem üzerinde, farklı üniversitelerde veya lisans/ön lisans düzeyindeki öğrencilerinin özelikleri (sınıf ortamları, internete erişim, öğretimden beklenti) farklı olabileceği için lisans veya ön lisans öğrencileri ile gerçekleştirilebilir.

\section{Yazarların Katkı Oranı}

Bu makaleye birinci yazarın $\% 50$, ikinci yazarın $\% 50$ oranında katkısı vardır.

\section{Çıkar Çatışması}

$\mathrm{Bu}$ çalışmada çıkar çatışması teşkil edebilecek bir durum yoktur.

\section{Kaynaklar}

Al, U. ve Madran, O. 2004. Web tabanlı uzaktan eğitim sistemleri: Sahip olması gereken özellikler ve standartlar. Bilgi Dünyası, 5(2), 259-271.

Aldemir, Ö. (2017). Endüstri 4.0'ın teknoloji kabul modeli kapsamında değerlendirilmesine yönelik üniversite ögrencileri üzerine bir araştırma. Yüksek Lisans Tezi. Ege Üniversitesi, Soyal Bilimler Enstitüsü, İzmir.

Bozkurt, A. (2017). Türkiye'de uzaktan eğitimin dünü, bugünü ve yarını. Açıköğretim Uygulamaları ve Araştırmaları Dergisi, 3(2), 85-124.

Büyüköztük Ş., Çakmak E., Akgün Ö., Karadeniz Ş. ve Demirel F. (2016). Bilimsel araştırma yöntemleri. Ankara: Pegem Yayınc1lık.

Cansu, T. (2010). Anadolu Üniversitesi ilkögretimde teknoloji uygulamaları e-sertifika programının ögrenen görüşüne göre bağlam, girdi, süreç ve ürün (CIPP) modeli ile değerlendirilmesi. Yüksek Lisans Tezi. Anadolu Üniversitesi, Sosyal Bilimler Enstitüsü, Eskişehir. 
Çelik, K. (2018). Genişletilmiş teknoloji kabul modeli: Uzaktan ĕgitim öğrencileri üzerine bir araştırma. Doktora Tezi. Gazi Üniversitesi, Bilişim Enstitüsü, Ankara.

Efiloğlu Kurt, Ö. (2015). Defining university students' perspectives on distance learning with integration of TAM and IS success model. Uluslararası Alanya İsletme Fakültesi Dergisi, $7(3), 223-234$.

Elitaş, T. (2019). Uzaktan eğitim lisans sürecinde yeni iletişsim teknolojileri: Atatürk Üniversitesi uzaktan eğitim merkezi. Doktora Tezi. Marmara Üniversitesi, Sosyal Bilimler Enstitüsü, İstanbul

Eren, A. ve Kaya, M.D. (2017). Üniversite öğrencilerinin uzaktan eğitim sistemine bakış açılarının teknoloji kabul modeli ile incelenmesi. YYÜ Sosyal Bilimler Enstitüsü Dergisi, 1(35), 233252.

Freeze, R.D., Alshare, K.A., Lane, P.L. and Wen, H.J. (2010). IS success model in e-learning context based on students' perceptions. Journal of Information Systems Education, 21(2), 173-184.

İsman, A. and Dabaj, F. (2005). Diffusion of distance education in North Cyprus. Turkish Online Journal of Distant Education, 6(4), 59-65.

İşbulan, O. (2012). Öğretmen adaylarının eğitim amaçlı Facebook kullanımlarının teknoloji kabul modeline göre incelenmesi ve geliştirilmesi. Yüksek Lisans Tezi. Sakarya Üniversitesi, Eğitim Bilimleri Enstitüsü, Sakarya.

Karaman, S., Özen, Ü., Yıldırım, S. ve Kaban, A. (2009, 11-13 Şubat). Açık kaynak kodlu öğretim yönetim sistemi üzerinden internet destekli (harmanlanmış) ögrenim deneyimi. XI. Akademik Bilişim Konferanst. Harran Üniversitesi, https://ab.org.tr/ab09/kitap/karaman_ozen_AB09.pdf adresinden 01.06.2021 tarihinde erişilmiştir.

Karasar, N. (2012). Bilimsel araştırma yöntemleri. Ankara: Nobel Yayınevi.

Karataş, H. (2007). Yıldız Teknik Üniversitesi Modern Diller Bölümü İngilizce II dersi öğretim programinın ögrretmen ve ögrenci görüşlerine göre bağlam, girdi, süreç ve ürün (CIPP) modeli ile değerlendirilmesi. Yüksek lisans tezi. Yıldız Teknik Üniversitesi, Sosyal Bilimler Enstitüsü, İstanbul.

Kırık, A. M. (2014). Uzaktan eğitimin tarihsel gelişimi ve Türkiye'deki durumu. Marmara İletişim Dergisi, 21, 73-94. https://doi.org/10.17829/midr.20142110299

Kudryavtseva, M. G. (2014). Possibilities of distance learning as a means of foreign language learning motivation among students of economics. Procedia-Social and Behavioral Sciences, 152, 1214-1218. https://doi.org/10.1016/j.sbspro.2014.09.301

Lee, M. K., Cheung, C. M. and Chen, Z. (2005). Acceptance of internet-based learning medium: The role of extrinsic and intrinsic motivation. Information and Management, 42(8), 1095-1104. https://doi.org/10.1016/j.im.2003.10.007

Lin, H. F. (2007). Measuring online learning systems success: Applying the updated DeLone and McLean model. Cyberpsychology and Behavior, 10(6), 817-820. https://doi.org/10.1089/cpb.2007.9948

Moore, M. G. and Kearsley, G. (1995). Distance education: A system view. Belmont: Wadsworth.

Ornstein, A. C. and Hunkins, F. P. (2004). Curriculum: Foundations, principles, and issues. Boston, Mass: Allyn and Bacon. 
Orhan, A. (2016). Uzaktan eğitimle yürütülen yabancı dil dersi öğretim programının bağlam, girdi, süreç ve ürün (CIPP) modeli ile değerlendirilmesi. Yüksek Lisans Tezi. Düzce Üniversitesi, Sosyal Bilimler Enstitüsü, Düzce.

Özbay, Ö. (2015). Öğretim yönetim sistemi üzerinde üniversite (lisans) düzeyindeki ögrenci hareketliliğinin veri madenciliği yöntemleriyle analizi. Yüksek Lisans Tezi. Eğitim Bilimleri Enstitüsü, Başkent Üniversitesi, Ankara.

Özer, B. (2011). Uzaktan ĕgitim programlarının ögrrenci ve ögretim üyesi görüşleri açısından değerlendirilmesi (Sakarya Üniversitesi örneği). Yüksek Lisans Tezi. Abant İzzet Baysal Üniversitesi, Eğitim Bilimleri Enstitüsü, Bolu.

Paulsen, M. F. (2002). Online education systems: Discussion and definition of terms. NKI Distance Education, 202.

Ramayah, T., Ahmad, N. H. and Lo, M.C. (2010). The role of quality factors in intention to continue using an E-learning system in Malaysia. Procedia Social and Behavioral Sciences, 2(2), 5422-5426. https://doi.org/10.1016/j.sbspro.2010.03.885

Rovai, A. P. and Barnum, K. (2003). On-line course effectiveness: An analysis of student interactions and perceptions of learning. Journal of Distance Education, 18(1), 57-73.

Sezer, C. (2019). Bilişim teknolojileri ve yazılım dersinde öğrenme yönetim sistemi kullanımının ögrenci akademik başarı, tutum ve motivasyonuna etkisi. Yüksek Lisans Tezi. Necmettin Erbakan Üniversitesi, Eğitim Bilimleri Enstitüsü, Konya.

Solak, M. (2012). Öğretmenlerin akıllı tahta kullanımına karşı tutumlarının teknoloji kabul modeline göre incelenmesi. Yüksek Lisans Tezi. Sakarya Üniversitesi, Eğitim Bilimleri Enstitüsü, Sakarya.

Stufflebeam, D. L. (2003). The CIPP model for evaluation. Annual conference of the Oregon program evaluators network (OPEN). Portland: Oregon.

Şimşek, H., İslim, Ö. ve Öztürk, N. (2019). Yükseköğretimde kalite arayışında bir gösterge olarak öğrenci memnuniyeti: Bir ölçek geliştirme çalışması. Trakya Ĕgitim Dergisi, 9(3), 380-395.

Tokmak, H.C., Baturay, H.M. and Fadde, P. (2013). Applying the context, input, process and product evaluation model for evaluation, research and redesign of an online master's program. The International Review Research in Open and Distance Learning, 14(3), 273-293.

Tunç, F. (2010). Evaluation of an English language teaching program at a public university using CIPP model. Yüksek Lisans Tezi. Orta Doğu Teknik Üniversitesi, Sosyal Bilimler Enstitüsü, Ankara.

Ünal, M. (2011). Avrupa Birliği Erasmus ögrenci ögrenim hareketliliği programının CIPP (bağlam, girdi, süreç, ürün) modeline göre değerlendirilmesi. Doktora Tezi. Gazi Üniversitesi, Eğitim Bilimleri Enstitüsü, Ankara.

Yarmohammadian, M.H., Ahmadi, A., Sadrian, M. and Fooladvand, M. (2011). Evaluation of distance education programs based on the NADE-TDCE 2009-2010. Procedia-Social and Behavioral Sciences, 28(1), 117-119.

Yıldırır, S.C. ve Burçin, K. (2019). Mobil uygulama kullanımının benimsenmesi: Teknoloji kabul modeli ile bir çalışma. Kafkas Üniversitesi İdari ve İktisadi Bilimler Fakültesi Dergisi, 10(19), 22-51. 


\section{Extended Abstract}

\section{Introduction}

Online learning environments emerged with the rapid development of the technology in the 21st century have led to the development of Learning Management Systems (LMS), which is an important milestone for distance education. LMSs are defined as a term that organizes online learning services which include the organization of user groups such as Access control, homework system, material sharing, assessment and evaluation, as well as providing, discussing and evaluating learning content for students, teachers and administrators ( $\mathrm{Al}$ and Madran, 2004; Karaman, 2009; Paulsen, 2002; Sezer, 2019). Internet-based distance education, which was first used in Turkey in 1998 at the Middle East Technical University, has become popular in parallel with the development of technology since then. Elitaş (2017) states that 82 out of 196 universities in Turkey use distance education as an alternative way to formal education in undergraduate, master and doctorate education. Due to the Covid-19 epidemic, it is known that LMSs, which offer internet-based distance education, are used in all universities with the transition to distance education. One of these LMSs is the platform called Ahi Competence Based Education Portal (AYDEP) used in Kırşehir Ahi Evran University (KAEU). In this study, it is aimed to evaluate AYDEP Learning Management System and the process of graduate course activities conducted with distance education through AYDEP LMS. The CIPP Program Evaluation Model, developed by Stufflebeam, was chosen for the evaluation of the graduate course activities carried out through AYDEP LMS. While the context and input dimensions of the model are used in the evaluation of AYDEP LMS, the process dimension is used in the evaluation of the graduate activities. In this context, answers to the following questions will be sought in the study:

1. What are the students' views on the AYDEP LMS and the process dimension of the course activities carried out through this system?

2. Do students' views differ according to gender, program type and department?

3. What are the lecturers' views on the AYDEP LMS and the process dimension of the course activities conducted through this system?

4. Do lecturers' views differ according to gender, title and department?

\section{Method}

In this study, descriptive research (scanning) model, one of the quantitative research methods, was used. Karasar (2013) defines this model as "a research approach that aims to describe a past or current situation as it is". In this study, it is aimed to reveal the current situation of the AYDEP LMS and the course process carried out through this system. The universe of the study consists of 171 students who are studying at KAEU Institute of Social Sciences in the 2020-2021 academic year and 40 lecturers who have lectures in graduate programs. AYDEP evaluation and CIPP Model Process Evaluation questionnaires were used as data collection tools which were developed by the researchers. The link address of the research questionnaires was sent to the students by text message and by e-mail to the lecturers. Participants answered the questionnaire via Google forms. Descriptive statistics were used to analyze the data. In this context, frequencies, percentiles and arithmetic means were calculated. Independent samples t-test and One-Way Analysis of Variance (ANOVA) were used to reveal whether the items, whose arithmetic averages were calculated, differ according to the variables of gender, program type, department and title.

\section{Findings}

According to the research findings, the mean of the items in the perceived benefit group related to AYDEP LMS is at the level of "agree" and "completely agree" in both student and lecturer questionnaire. In the perceived ease of use group, the item means are at the level of "completely agree" in both student and lecturer questionnaire. In the system features and improvements group, the item means are at the level of "agree" and "completely agree" in both student and the lecturer 
questionnaire. The general mean of items related to AYDEP LMS is at the level of "completely agree" in both student and lecturer questionnaire. In the findings obtained from the student questionnaire, while there is a significant difference in five items according to the type of program and one item according to gender, there is no significant difference according to the variable of the department. In the findings obtained from the lecturer questionnaire, while there is a significant difference in only one item according to the gender, there is no significant difference according to the variable of the title and the department.

All items related to graduate course activities are at the level of "agree" and "completely agree" in both student and lecturer questionnaire. In the findings obtained from the student questionnaire, while there is a significant difference in seven items according to the type of program and two items according to gender, there is no significant difference according to the variable of the department. In the findings obtained from the lecturer questionnaire, while there is a significant difference in two items according to the gender, there is no significant difference according to the variable of the title and the department. The general mean of the items related to graduate course activities is at the level of "agree" in both student and lecturer questionnaire.

\section{Conclusion, Discussion and Recommendations}

According to the findings obtained from the AYDEP Evaluation Questionnaire, the general average is at the level of "completely agree". Considering that the items in the questionnaire are grouped under the titles perceived benefit, perceived ease of use and system features/improvements, it can be concluded that the participants have enough knowledge about AYDEP LMS, find the system easy and useful, and they are satisfied with the features of the system. There are various studies in the literature whose findings similar to this result (Aldemir, 2017; Çelik, 2018; Eren and Kaya, 2017; Freeze vd. 2010; Lee vd. 2005; Lin, 2007; Ramayah vd. 2010; Solak, 2012; Y1ldırır and Kaplan, 2019).

According to the findings obtained from the CIPP Model Process Evaluation Questionnaire, the general average of the responses is at the level of "Agree". In this context, it is concluded that the two groups have positive opinions about the course activities according to the CIPP model process dimension evaluation criteria. There are various studies in the literature whose findings similar to this result (Cansu, 2010; Karataş, 2007; Orhan, 2016; Özer, 2011; Ünal, 2011).

In this study, in which the AYDEP LMS and the graduate course activities conducted through this system were investigated, it was concluded that the participants were generally satisfied with the AYDEP LMS and the course activities carried out. The suggestions developed based on the results of the study are as follows:

1. Course hours on AYDEP can be increased

2. The infrastructure of the AYDEP LMS (server, etc.) can be developed.

3. Screen sharing of AYDEP LMS and usage of this feature can be reviewed.

4. Different methods and techniques can be used in the course activities conducted through AYDEP LMS.

5. LMSs can be evaluated with a scale prepared by examining the theories regarding various technology acceptance models.

6. LMSs can be evaluated employing all dimensions of the CIPP evaluation model or different evaluation models.

7. The study can be carried out on a larger sample or on LMS of different universities.

8. The study can be carried out undergraduate or associate degree students. 